\title{
Baurusuchus salgadoensis, a New Crocodylomorpha from the Bauru Basin (Cretaceous), Brazil
}

\author{
Ismar de Souza Carvalho ${ }^{1}$, Antonio de Celso Arruda Campos ${ }^{2}$ and Pedro Henrique \\ Nobre $^{1}$ \\ 1 Universidade Federal do Rio de Janeiro. Departamento de Geologia, CCMN/IGEO. 21.949-900 Cidade Universitária - Ilha \\ do Fundão. Rio de Janeiro - RJ, Brazil, E-mail: ismar@geologia.ufri.br \\ ${ }^{2}$ Museu de Paleontologia de Monte Alto. Praça do Centenário, Centro de Artes s/nº. 15.910-000 Monte Alto - SP, Brazil, \\ E-mail:mpaleo@montealto.sp.gov.br
}

(Manuscript received October 3, 2003; accepted June 20, 2004)

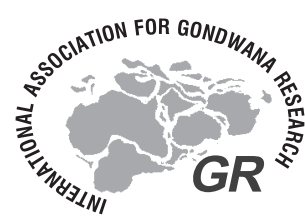

\begin{abstract}
Baurusuchus salgadoensis is a new baurusuchid crocodylomorph from Bauru Basin (Cretaceous), Brazil, partially preserved through a complete skull. The fossil comes from a fine sandstone sequence of Adamantina Formation, General Salgado County, São Paulo State. The sedimentary sequence where it was found, located in Fazenda Buriti, is considered Turonian-Santonian in age. The described species - Baurusuchus salgadoensis sp. nov. - is a baurusuchid with an antorbital fenestra, double external nares with a bony septum, two well-fused supraorbitals, the supratemporal fenestrae larger than the orbits and a quadrangular-shaped laterotemporal fenestra. The position of the external nares, located on anterior and terminal portion of the rostrum together with the theropod-like lateral compression of the snout and teeth are indicators that Baurusuchus salgadoensis was a terrestrial crocodyliform. This was a carnivorous species and the lateral compression of the rostrum could be interpreted as a mechanism to increase the skull resistance forces during biting. The pointed, conical teeth, some with crenulated borders, could be used to perforate and to carve the prey. The geological context of Baurusuchus salgadoensis indicates that it probably lived in a hot and arid climate.
\end{abstract}

Key words: Crocodylomorpha, Baurusuchus salgadoensis, Baurusuchidae, Cretaceous, Brazil.

\section{Introduction}

The Bauru Basin (Cretaceous), located in southeastern Brazil, occupies an area of $370,000 \mathrm{~km}^{2}$ (Fig. 1). During the South Atlantic opening the continental rupture originated this inland basin by the process of thermomechanical subsidence (Fernandes and Coimbra, 1996, 1999; Fulfaro et al., 1994) of volcanic rock. It comprises a Cretaceous sequence, with at least 300 meters of siliciclastic sediments. The age of the Bauru Basin ranges from Aptian to Maastrichtian (Fulfaro et al., 1994) and there are different proposals to the lithostratigraphy (Soares et al., 1980; Fernandes and Coimbra, 1992, 1996).The Bauru Basin sediments are generally included in the Caiuá and Bauru groups, although some authors (Fulfaro et al.,1999) proposed that the Caiuá Group is part of a separated pre-Bauru Basin of Aptian-Albian age, named Caiuá Basin. The Bauru Group was divided by Fernandes and Coimbra (1996) in three formations, namely Adamantina, Uberaba and Marília. The Adamantina Formation (Turonian-Santonian age, Castro et al., 1999; Dias-Brito et al., 2001) is a sequence of fine sandstones intercalated by mudstones, siltstones and clayish sandstones. The lowermost part of this unit was redefined by Batezelli et al. (1999) as the Araçatuba Formation. The Uberaba Formation (ConiacianCampanian, Goldberg and Garcia, 2000) is composed of fine greenish sandstones interbedded by siltstones, coarse sandstones, mudstones and volcanoclastics. The Marília Formation was formally proposed by Soares et al. (1980) as a sequence of coarse to conglomeratic sandstones, mudstones and carbonate levels. The sandstones are mainly classified as subfeldsarenites and feldspathic litarenites (Garcia et al., 1999; Alves and Ribeiro, 1999; Andreis et al., 1999). The age of these deposits based on the abundant vertebrate fauna is considered as Campanian-Maastrichtian (Bertini, 1993). Dias-Brito et al. (2001) based on charophyte and ostracods, established a Maastrichtian age.

Throughout the Upper Cretaceous, there was an alternation between severely hot dry and rainy seasons, 
and a greatly diverse fauna and flora was established in the basin. Charophyta algae, pteridophyte sporocarpes (Marsiliaceae), coniferophyte logs, ostracods, gastropods, bivalves, invertebrate and vertebrate ichnofossils as well a diversified vertebrate fauna of fishes, amphibians, reptiles (lizards, ophidians, turtles, crocodylomorphs, Dinosauria) and mammals are frequent (Roxo, 1936; Barbosa, 1955; Petri, 1955; Suarez and Arruda, 1968; Arid and Vizotto, 1965, 1971; Estes and Price, 1973; Lima et al., 1986; Baez and Peri, 1989; Bertini, 1993, 1994a, b; Bertini et al., 1993; Kischlat et al., 1994; Manzini et al., 1996; Castro et al., 1999; Magalhães Ribeiro and Ribeiro, 1999; Senra and Silva e Silva, 1999; Magalhães Ribeiro, 2000; Musacchio, 2000; Campos et al., 2001; GobboRodrigues et al., 2001).
The oldest sediments in this basin (Adamantina Formation), Turonian-Santonian in age (Castro et al., 1999) were deposited in a lacustrine environment (Batezzelli et al., 1999). Progressive increase in aridity due to the persistence of a hot climate and to topographic heights surrounding the basin, allowed the establishment of alluvial plains, braided rivers and small temporary ponds (Mezzalira, 1980; Campanha et al., 1992; Silva et al., 1994; Etchebehere et al., 1999; Goldberg and Garcia, 2000). The new baurusuchid was found in this palaeoenvironmental setting. The specimen was collected in fine sandstones deposited through sudden floods on alluvial plains during a dry and hot season (Fig. 2). A great amount of crocodylomorph eggs and eggshells also occur nearby in correlated stratigraphical levels.

\section{BAURU BASIN}

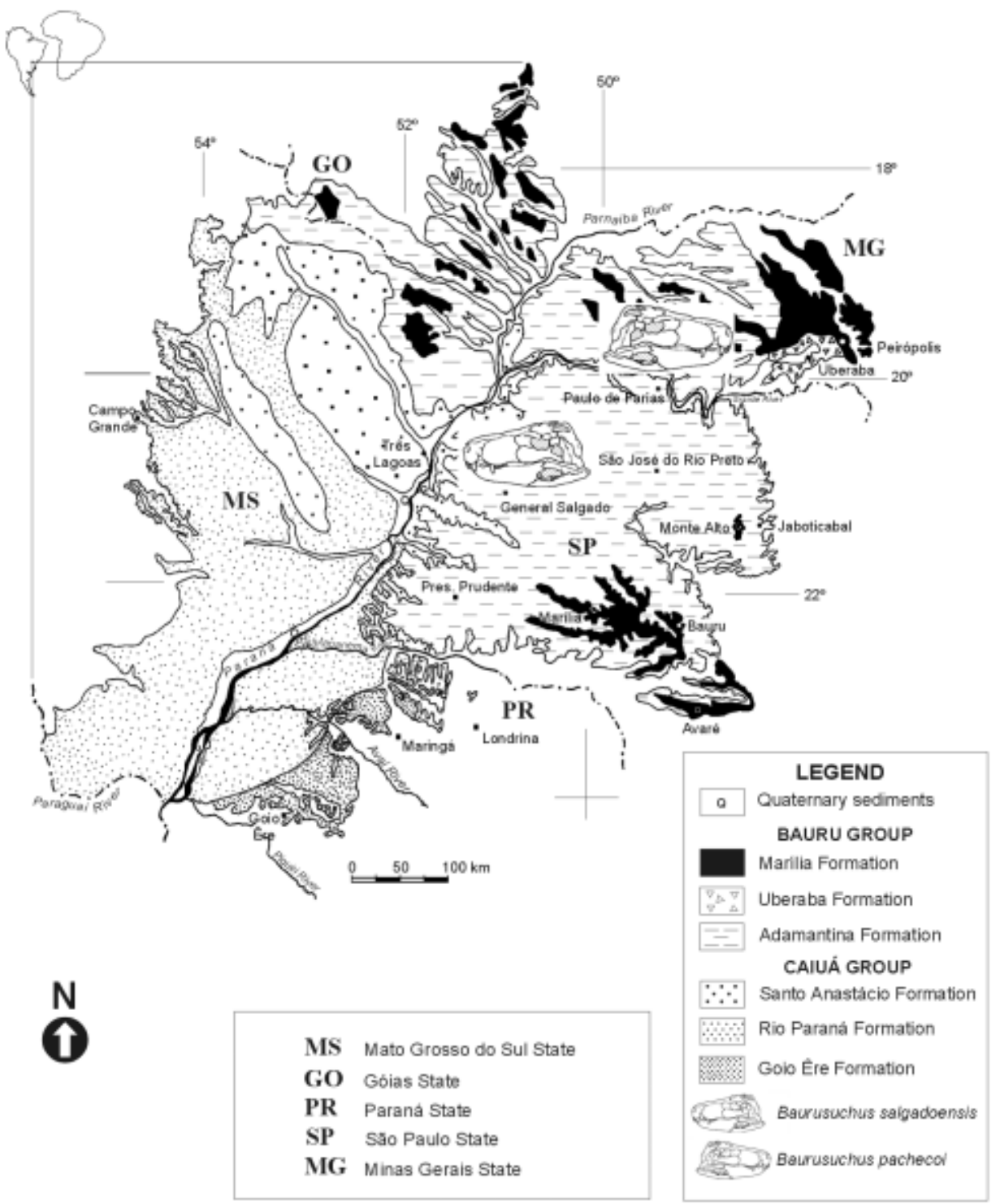

Fig. 1. Geological map of the Bauru Basin, southern Brazil in the context of Gondwana (80 Ma) (modified from Fernandes and Coimbra, 1996). 

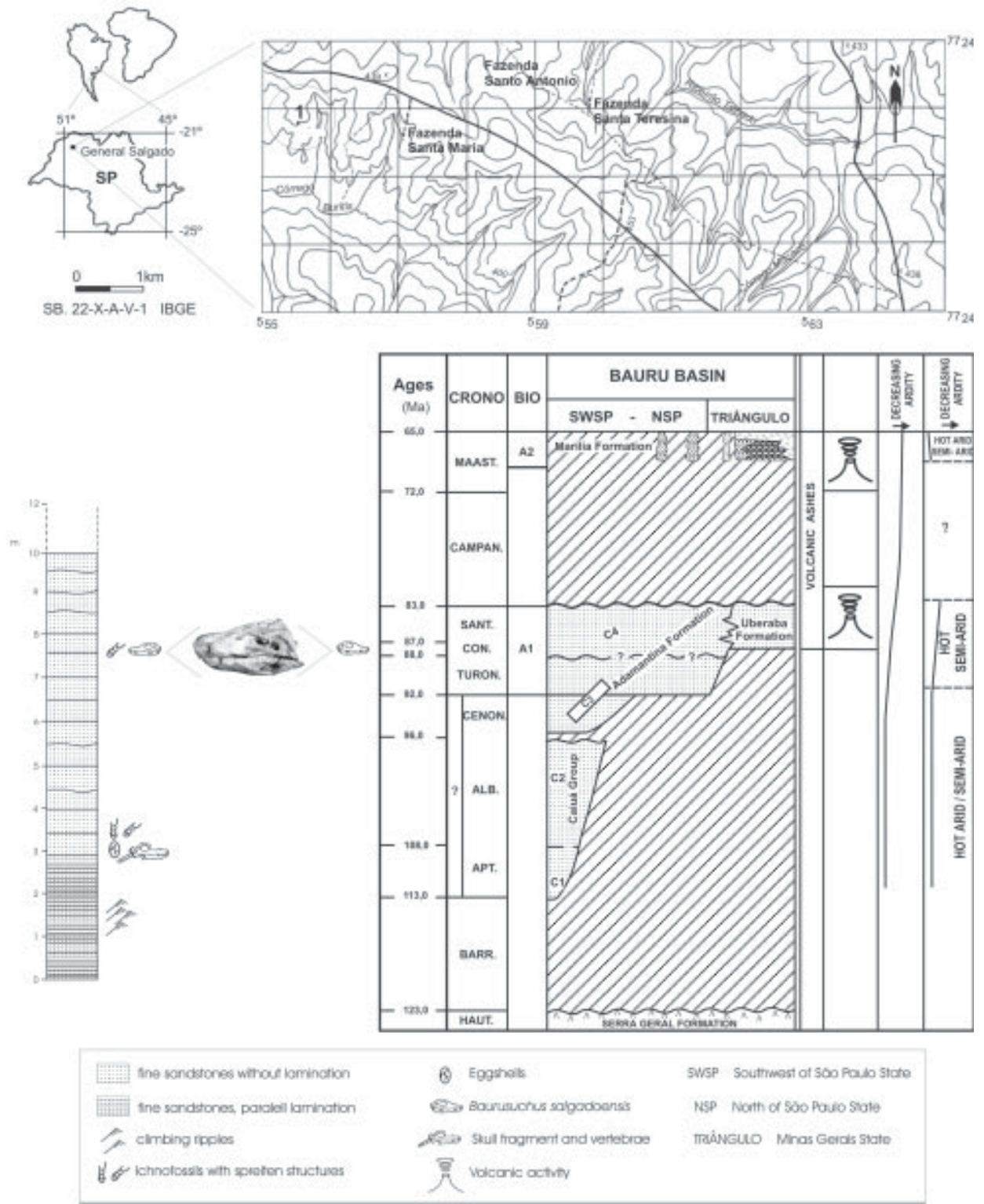

Fig. 2. Location map of Fazenda Buriti, in General Salgado County, Brazil, and the stratigraphic level within the Adamantina Formation, which yielded the new baurusuchid occurrence. Stratigraphic chart according to Dias-Brito et al. (2001).

The fossil was excavated at Fazenda Buriti - Prudêncio e Morais district, municipality of General Salgado (São Paulo State, Brazil) at $20^{\circ} 33^{\prime} 57,23^{\prime \prime} \mathrm{S}$ and $50^{\circ} 28^{\prime} 03,97^{\prime \prime} \mathrm{W}$.

\section{The Bauru Basin Crocodylomorphs}

The crocodylomorphs from this basin comprise at least five distinct groups: notosuchids, trematochampsids, peirosaurids, baurusuchids and an unnamed group.

The oldest ones, of Turonian-Santonian age, are the notosuchids (Mariliasuchus amarali Carvalho and Bertini, 1999) of the Adamantina/Araçatuba Formation (Bertini and Carvalho, 1999; Carvalho and Bertini, 1998; Carvalho and Bertini, 1999, 2000; Castro et al., 1999). Price (1950a) also described a Maastrichtian notosuchid from the Marília Formation (São Paulo State) named as Sphagesaurus huenei, although Bonaparte (1978) and Gasparini et al. (1991) considered that the dental structure and tooth replacement do not correspond to any known notosuchid. Therefore, the analysis of an almost complete skull of Sphagesaurus huenei by Pol (2003) allowed to include it in a monophyletic group considered as Ziphosuchia/ Notosuchia.

In Maastrichtian rocks of the Marília Formation (Peirópolis-Uberaba, Minas Gerais State) Itasuchus jesuinoi was found. Identified as a Goniopholidae by Price (1955) 
and ascribed the latter to the Trematochampsidae (Buffetaut, 1985), Gasparini et al. (1991) considered that the characters exhibited by Itasuchus do not allow confirmation of its affinities to the previously cited taxa.

The peirosaurids are represented by Peirosaurus tormini Price, 1955 and Uberabasuchus terrificus Carvalho, Ribeiro and Avilla, 2004, both from the Marília Formation (Peirópolis, Uberaba, Minas Gerais State). They are grouped in the Peirosauridae, a family established by Gasparini (1982).

Goniopholis paulistanus Roxo, 1936 and ?Brasileosaurus pachecoi Huene, 1931, both from the Adamantina Formation (São Paulo State), reveal too few diagnostic aspects, as already pointed out by Price (1950b) and Bertini (1994a), to allow an adequate systematic classification. There is also an undescribed "mesosuchian" from the Adamantina Formation, São José do Rio Preto County , São Paulo State (Brandt Neto et al., 2001) and another one from the Marília Formation, Peirópolis locality (Azevedo and Campos, 1993), Minas Gerais State.

The baurusuchids are found in the Adamantina Formation (Turonian-Santonian, São Paulo State). The first described baurusuchid species was Baurusuchus pachecoi Price, 1945. Another baurusuchid from this formation is Stratiotosuchus maxhechti Campos, Suarez, Riff and Kellner, 2001. There are also other occurrences of Baurusuchus sp. in Adamantina Formation referred by Brandt Neto et al. (1991, 1992) and Bertini et al. (1999). This diversity of baurusuchids is probably related to the wide distribution area and also to the time range of this lithostratigraphic unit, allowing in this way speciation.

\section{Systematic Palaeontology}

The classification of the new specimen was based on the comparative studies by Price (1945), Gasparini (1982), Gasparini et al. (1991) and Carvalho et al. (2004). The osteology terms follow Colbert (1946), Romer (1956), Hecht and Tarsitano (1983), Gasparini et al. (1991), Nobre and Carvalho (2001) and Richardson et al. (2002). It was attributed to Baurusuchus Price, 1945 because it presents the same skull pattern, but a detailed osteological analysis allowed the definition of a new species.

Crocodylomorpha Walker, 1970

Crocodyliformes Benton and Clark, 1988

Baurusuchidae Price, 1945

Baurusuchus Price, 1945

Type-species: Baurusuchus pachecoi Price, 1945

Baurusuchus salgadoensis sp. nov.

(Figs. 3, 4, 5, 7A, 8; Table 1, 2)

Holotype: Museu de Paleontologia de Monte Alto, Monte Alto County, São Paulo State, Brazil. Skull and mandible. MPMA 62-0001-02.
Locality: Fazenda Buriti, Prudêncio e Morais District, General Salgado County, São Paulo State, Brazil. 20 33' $57,23^{\prime \prime} \mathrm{S}$ and $50^{\circ} 28^{\prime} 03,97^{\prime \prime} \mathrm{W}$.

Stratigraphic context: Bauru Basin, Adamantina Formation. Fine reddish sandstone. Upper Cretaceous: TuronianSantonian.

Species etymology: salgadoensis referring to the county of General Salgado, São Paulo State, Brazil, where the specimen was found.

Diagnosis: The skull is elongated and has a laterally compressed rostrum. The cranial table is slightly depressed in relation to the dorsal border of the snout, whose tip points downward. There is a small elliptical antorbital fenestra located on the maxilla aligned with the upper border of the orbit. There is also another smaller rounded depression located in the left jugal. The orbits are elliptical and laterally positioned. Each one is covered by two

Table 1. Baurusuchus salgadoensis sp. nov. Holotype MPMA 62-0001-02. Measurements of the main anatomical dimensions of the skull and mandible.

Measurement $\mathrm{mm}$

Skull length (distance between occipital condyle to rostrum extremity)

Distance between border of skull to rostral extremity

Skull posterior width (distance between the quadrate external borders)

Skull anterior width (distance between the borders of premaxilla at the third tooth level)

Orbit width (distance between the two orbits in the contact of anterior and posterior supraorbitals)

Rostral width in lateral view (distance between the tip of rostrum to the base of the premaxillar first alveolum)

Skull posterior width in lateral view (distance between the border of the supraoccipital to the extremity of the quadrate) Skull with mandibular posterior width in lateral view (distance between the border of the supraoccipital to the extremity of the articular)

Mandibular length (distance between the extremities of articular and dentary)

Mandibular width (in the middle of the mandibular fenestra) Orbit length

Orbit width

Laterotemporal fenestra length

Laterotemporal fenestra width

Antorbital fenestra length

Antorbital fenestra width

Mandibular fenestra length

Mandibular fenestra width

Supraorbital fenestra length

Supraorbital fenestra width

Supratemporal fenestra length

Supratemporal fenestra width

External narial length

External narial width

Palatal fenestra length

Palatal fenestra width

Angle between the longitudinal axis of the skull roof and the quadrate 
supraorbital bones. Between them there is an elliptical fenestra. The supratemporal fenestrae are large, triangular shaped and a little larger than the orbit. The quadrangular laterotemporal fenestrae are separated from the orbits by a thin flattened, inward postorbital bar. There is a great reduction in the number of teeth: four premaxillary, five maxillary and ten dentary. All of these are located anterior to the antorbital fenestra. The surface of the skull is irregularly sculptured by grooves and ridges. In the anteriormost extremity of the rostrum there is a double external naris, frontally oriented and separated by a thin bone bar. The nasals participate in the construction of the margins of the external nares, projecting in their extremes a thin bony lamina that produces an internarial wall. This divides the narial aperture into two distinct nares, and the complete septum contacts an upward projection of the premaxilla (a rostral bone). Posteriorly, the nasals meet at the prefrontal through two thin lateral projections. The premaxilla-maxilla contact presents a clavate opening that receives a large third dentary tooth. The supraorbital is a double bone projected outwards from the orbit. It covers completely the upper border of the orbital region. Between it and the surrounding bones there is an elliptical fenestra whose main axis is perpendicular to the length of the skull. The prefrontal has a triangular shape and is higher than the nasal and frontal. The frontal is a fused triangularshaped bone bordered by the prefrontal, anterior supraorbital, parietal and postorbital. The area where the frontal is located is depressed in relation to the posterior border of the prefrontals. The parietal is a narrow triradiate bone that borders the inner margins of the supratemporal fenestrae. This bone is located higher than the frontal. As it is very narrow between the two supratemporal fenestrae it has the aspect of a raised ridge. The supratemporal fenestra is wider than the orbit. The margin in contact with the parietal is convex, while it is straight in the opposite border. They extend beyond the limits of the laterotemporal fenestrae, reaching the posterior border of the skull. The quadratojugal is an elongated bone, straight, with an ascending process that delimits the posterior border of the quadrangular-shaped laterotemporal fenestra. The quadrate is highly inclined, with two terminal condyles displaced beyond the level of the occipital condyle. They contact the quadratojugal, squamosal, basisphenoid and the paraoccipital process. The condylar surface faces posteroventrally. The supraoccipital is a rhomboid-shaped bone that contacts the parietal, squamosals and exoccipitals. It presents a dorsomedial projection that reaches the cranial roof and separates the parietal from the posterior margin of the

Table 2. Baurusuchus salgadoensis sp. nov. Holotype MPMA 62-0001-02. Dentition characteristics of premaxillae, maxillae and dentaries.

\begin{tabular}{|c|c|c|c|}
\hline & Left & & Right \\
\hline $\begin{array}{l}\text { Size } \\
(\mathrm{mm})\end{array}$ & Premaxilla & $\begin{array}{l}\text { Size } \\
(\mathrm{mm})\end{array}$ & Premaxilla \\
\hline 28 & $1^{\text {st }}$ tooth - without serrations, complete, conical & 23 & $1^{\text {st }}$ tooth - anterior serrations, partially broken, conical \\
\hline 30 & $2^{\text {nd }}-$ serrations on both sides, complete, conical & 16 & $2^{\text {nd }}-$ broken at its base, conical \\
\hline 30 & $3^{\text {rd }}-$ without serrations, broken in the extremity, conical & 25 & $3^{\text {rd }}-$ posterior serrations, partially broken \\
\hline- & $\begin{array}{l}4^{\text {th }} \text { - broken at its base ( } 5 \mathrm{~mm} \text { diameter and estimate } \\
\text { length } 15 \mathrm{~mm})\end{array}$ & 15 & $4^{\text {th }}-$ anterior serrations, conical \\
\hline & Maxilla & & Maxilla \\
\hline 8 & $1^{\text {st }}$ tooth - without serrations, very small, conical & 10 & $1^{\text {st }}$ tooth - without serrations, very small \\
\hline - & $2^{\text {nd }}-$ broken at its base (probably same size of the $3^{\text {rd }}$ tooth) & 17 & $2^{\text {nd }}-$ without serrations, broken in the extremity \\
\hline 35 & $3^{\text {rd }}$ serrations anterior and posterior, complete, conical, large & 35 & $3^{\text {rd }}-$ without serrations, broken in the extremity \\
\hline- & $4^{\text {th }}-$ broken at its base (estimate length $35 \mathrm{~mm}$ ) & 30 & $4^{\text {th }}-$ anterior and posterior serrations, complete \\
\hline- & $5^{\text {th }}-$ broken at its base (estimate length $20 \mathrm{~mm}$ ) & 15 & $5^{\text {th }}-$ anterior serrations, complete \\
\hline 15 & $\begin{array}{l}\text { Dentary } \\
1^{\text {st }}-\text { without serrations }\end{array}$ & - & $\begin{array}{l}\text { Dentary } \\
1^{\text {st }}-\text { broken at base, large size (estimate through the } \\
\quad 10 \mathrm{~mm} \text { diameter) }\end{array}$ \\
\hline 5 & $2^{\text {nd }}-$ not observed serrations, small size & & $2^{\text {nd }}-$ broken at its base, small \\
\hline- & $3^{\text {rd }}-$ broken at its base, small (base diameter similar to $5^{\text {th }}$ ) & 7 & $3^{\text {rd }}$ without serrations, broken at tip \\
\hline - & $\begin{array}{l}4^{\text {th }} \text { - broken at its base, the biggest (through the observation } \\
\text { of the alveolus diameter of } 20 \mathrm{~mm} \text { ) }\end{array}$ & 55 & $4^{\text {th }}-$ anterior serrations, the biggest \\
\hline 20 & $5^{\text {th }}-$ without serrations, conical & 17 & $5^{\text {th }}-$ without serrations, partially covered \\
\hline- & $6^{\text {th }}-$ not observed, covered by the $3^{\text {rd }}$ of the maxilla & 5 & $6^{\text {th }}-$ without serrations, small, broken at tip \\
\hline 5 & $7^{\text {th }}-$ without serrations, small size & 7 & $7^{\text {th }}-$ not observed serrations, partially covered \\
\hline 20 & $8^{\text {th }}-$ medium size, not completely observed & 10 & $8^{\text {th }}-$ without serrations, conical \\
\hline 22 & $9^{\text {th }}-$ big-sized, not completely observed & 28 & $9^{\text {th }}-$ anterior serrations, partially covered \\
\hline 20 & $\begin{array}{l}10^{\text {th }} \text { - posterior serrations, medium size, } \\
\text { not completely observed }\end{array}$ & - & $\begin{array}{l}10^{\text {th }} \text { - broken at its base ( } 5 \mathrm{~mm} \text { diameter and estimated } \\
\text { length } 10 \mathrm{~mm} \text { ) }\end{array}$ \\
\hline
\end{tabular}


cranial roof. The exoccipitals limit the upper margin of the foramen magnum and they are extended laterally becoming the paroccipital processes, which contact the quadrates. There is a large, rounded occipital condyle bordering the ventral margin of the foramen magnum.

The mandible is high, slightly projected forward and expanded anteriorly. The splenials participate in the mandibular symphysis. The mandible's outline in lateral view is straight, showing almost the same height along its length, except for a slight wave in the mandibular fenestra region. It is less sculptured than the skull roof. The dentary is the greatest portion of the mandibular length, comprising ten teeth. Its anteriormost part is flattened and bears six conical teeth, surpassed by the premaxilla. The biggest mandibular tooth (fourth of the dentary) fits in a clavate notch of the rostrum at the premaxilla-maxilla contact. Posteriorly the dentary presents a constriction (at the level of the third maxillary tooth) and becomes vertical and compressed. There are four more conical teeth of different sizes, the last two $\left(9^{\text {th }}\right.$ and $\left.10^{\text {th }}\right)$ are the largest. The dentary extends as far as the mandibular fenestra. The lower surface of the dentary presents a long symphysis, which extends as far as the position of the fourth maxillary tooth or eighth dentary tooth. There are few dentary teeth that present some kind of serrations in their carenae. The mandibular fenestra is very large, located in the same direction of the orbit and laterotemporal fenestra, although its rear margin extends beyond the posterior margin of the laterotemporal fenestra. Anteriorly, it is aligned with the orbit. The angular is very elongated, with the lower and upper borders nearly parallel to the jaw's external margins. Posteriorly, it is very straight, with a slight rise that forms the postarticular process. The surangular is slightly convex in the orbit direction. It composes the upper limit of the mandibular fenestra, bordering the dentary, angular and articular. The suture with the angular is straight. As the mandibular fenestra is very large it is relatively narrow in this area. The left articular is almost complete. Its inner surface presents two distinct fossae for the articulation of the quadrate condyles. There is a large retroarticular process that is aligned with the upper margin of the surangular. Its border is concave.

\section{Description}

Skull

The skull of Baurusuchus salgadoensis is elongated (rostrum and cranial table almost of same size) and has a laterally compressed rostrum (Figs. 3, 4). The left side of the skull is complete, while the right side is deformed with the loss of quadrate and the antorbital fenestra. The cranial table is slightly depressed in relation to the dorsal border of the snout, whose tip points downward. There is a small elliptical antorbital fenestra (preorbital fenestra) aligned with the upper border of the orbit, and also another smaller rounded depression located in the lower anterior region of the orbit. The orbits are elliptical and laterally positioned. Each one is covered by two supraorbital bones. Between them there is an elliptical fenestra. The anterior supraorbital has a rectangular shape and is bigger than the quadrangular posterior supraorbital. The supratemporal fenestrae are large, triangularly shaped and a little larger than the orbit. The quadrangular laterotemporal fenestrae are separated from the orbits by thin flattened, inset postorbital bars. There is a great reduction in the number of teeth: four premaxillary, five maxillary and ten dentary. The surface of the skull is irregularly sculptured by grooves and ridges.

The premaxillae are quadrangular-shaped bones, dorsally separated by the nasals and vertically disposed. In the anteriormost extremity of the rostrum there is a double external naris, frontally oriented and separated by a thin bone bar. The external nares are bordered by the premaxilla and the nasals, and there are smooth depressions on both sides of the premaxillary bones, around the external nares. Each premaxilla has four conical teeth which are regularly spaced. The first premaxillary tooth is positioned in the anteriormost portion of the rostrum. It is followed by a second tooth of almost equal size with badly preserved small serrations on its tip. The third tooth is the largest one. It presents a rounded crosssection. Serrations on their edges were not observed. The fourth and last premaxillary tooth is the smallest of this series. It shows small serrations on the anterior carinae and in cross-section has an elliptical shape.

The maxilla has a quadrangular shape. It contacts anteriorly the premaxilla through a clavate opening that receives a large fourth dentary tooth. The upper border contacts the nasal through along all its length and the posterior border contacts the lacrimal and jugal. In this region, on level with the lacrimal, there is a small elliptical fenestra, here considered as an antorbital fenestra. This structure is only observed on the left side of the skull since the equivalent on the right side was partially crushed by compression during fossilization. In the right maxilla, on the posterior border, there is a rounded foramen that probably allowed the last dentary tooth $\left(10^{\text {th }}\right)$ to fit. The maxilla is ornamented by small ridges and grooves on its surface. Ventrally, it is slightly convex and presents five conical teeth. All of them are located anteriorly to the antorbital fenestra and do not contact each other. These teeth are separated by short diastemas. The first three teeth are increasingly larger posteriorly. The first one is the smallest of this series, located at the border of the 


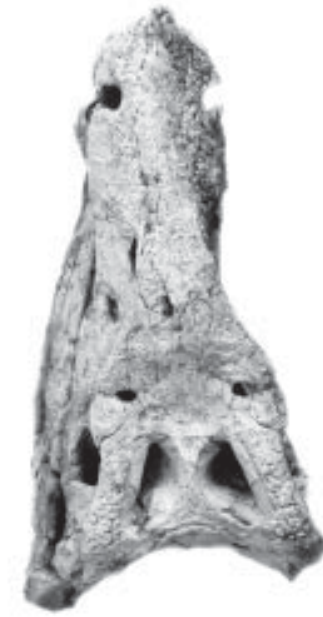

A

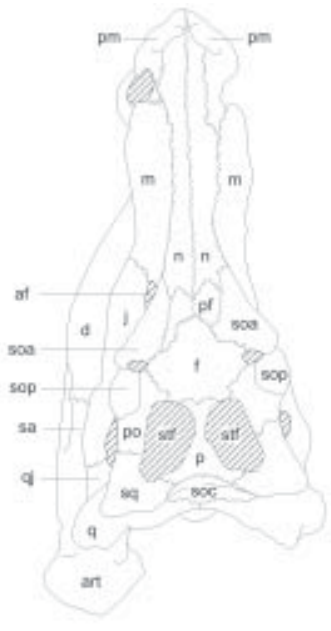

B

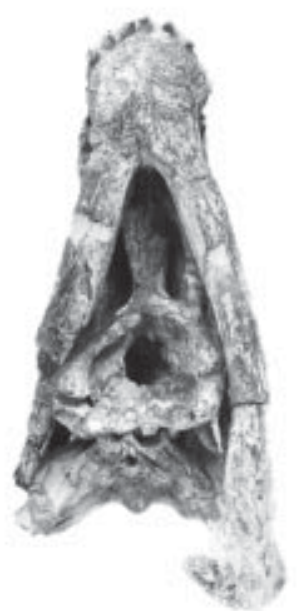

C

D

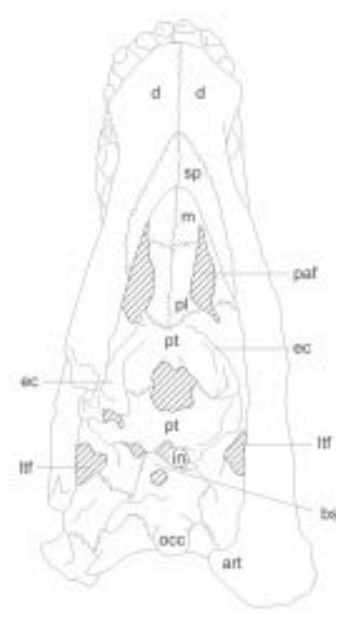
$10 \mathrm{~cm}$

Fig. 3. Baurusuchus salgadoensis sp. nov. specimen MPMA 62-000102. (A), (B) Dorsal view; (C), (D) ventral view of skull and mandible; (B) and (D) schematic drawings.

clavate opening at the premaxilla-maxilla contact. The second tooth is moderately compressed and presents finely serrated edges. The third maxillary tooth is the largest on the tooth row and also shows serrated carinae. The last two teeth present the same pattern. The fourth tooth is the second largest of this series, and the fifth has almost the same size as the second maxillary tooth. All these are located on the convex border of the maxilla.

The nasals are long and reach the anterior region of the rostrum. They border the premaxillae, in the anteriormost portion of the rostrum, the external nares. They are bordered by the premaxillae, maxillae, anterior supraorbitals, lacrimals and prefrontals. The nasals progressively narrow in the anterior region of the rostrum, although they present a slight constriction in the middle portion. They participate in the construction of the margins of the external nares, projecting at their extremes a thin bone lamina that produces an internarial wall (Fig. $5 \mathrm{~A}$, B). This divides the narial aperture in two distinct nares, and the complete septum contacts an upward projection of the premaxilla (a rostral bone). Posteriorly the nasals meet at the prefrontal through two thin lateral projections.

The lacrimals are rectangular-shaped, limited by the maxillae, nasals, jugals and anterior supraorbitals. They limit the anteriormost border of the orbit and the posteriormost border of the antorbital fenestrae. They are disposed vertically and can be observed only in lateral view.

The supraorbital is composed of two bones projected outwards from the orbit. It covers completely the upper border of the orbital region. The anterior supraorbital is rectangular and contacts the lacrimal, nasal, prefrontal and the posterior supraorbital. Between it and the surrounding bones there is an elliptical fenestra whose main axis is perpendicular to the length of the skull. The posterior supraorbital contacts the anterior supraorbital and the postorbital, it is smaller than the anterior supraorbital and presents a quadrangular shape. The latter bone is thicker and projects further outwards over the orbit. Both are slightly convex and are sculptured in the same pattern of the skull.

The jugal contacts the maxilla, lacrimal, quadratojugal and postorbital. The lower margin of the orbit is delimited by a concavity in the jugal. Posteriorly to the postorbital bar it is less high than anteriorly. The ascending process, that is a part of the postorbital bar, rises from the inner lateral surface of the jugal. It is thin, non-sculptured and slightly depressed. The anterior suture with the maxillary is relatively convex and it is straight with the lacrimal. At the anterior termination of the jugal there is a rounded depression, only observed at the left side. From this area, there is a triangular depression that extends backwards. Posteriorly, it limits ventrally the laterotemporal fenestra.

The prefrontal contacts the nasal, frontal and the anterior supraorbital. It is triangular in shape and is elevated relative to the nasal and frontal.

The frontal is a fused triangular bone bordered by the prefrontal, anterior supraorbital, parietal and postorbital. It contacts with the prefrontals through a bone projection. The borders with the last three bones are straight. The area where the frontal is located is depressed in relation to the posterior border of the prefrontals. It is not clear if this aspect (a concave area) is taphonomic, due differential compression of the skull.

The parietal is fused and contacts the frontal, postorbital, supraoccipital and squamosal. It is a narrow triradiate 


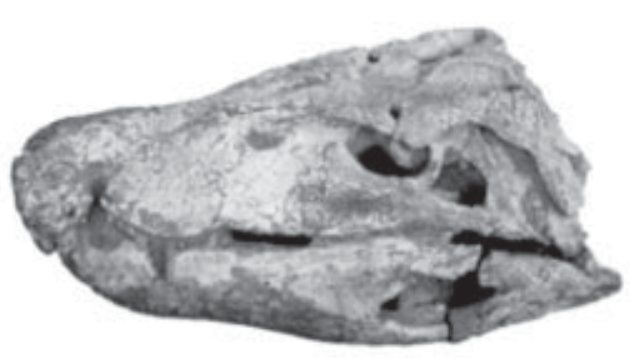

A

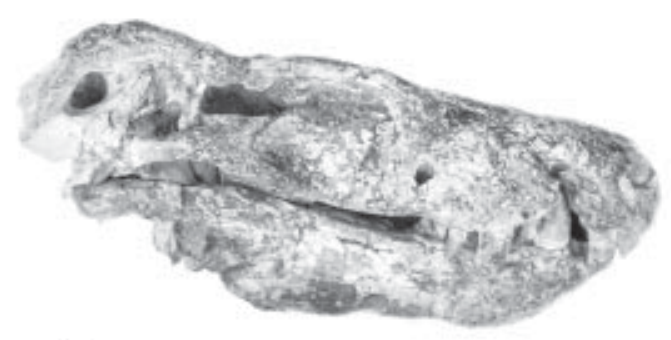

C

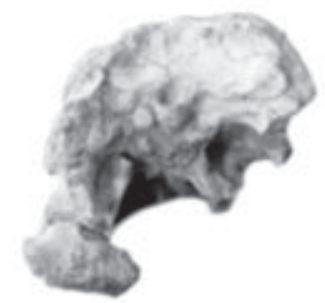

E

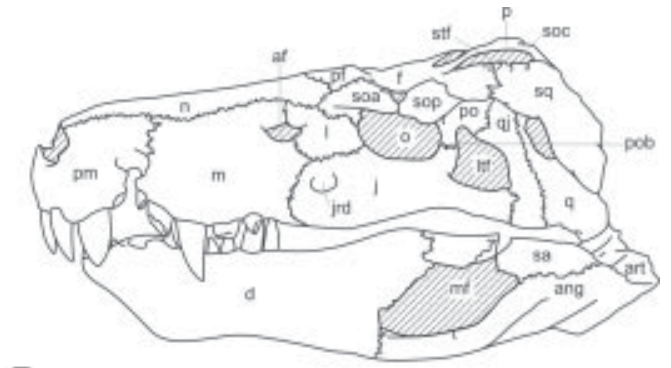

B

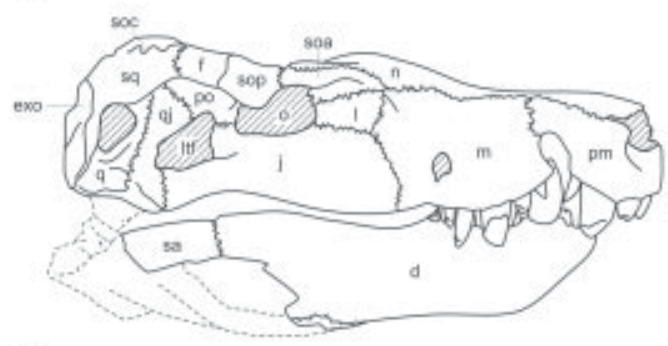

D

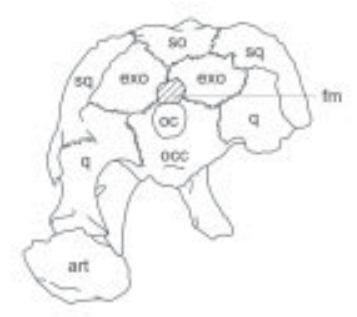

F

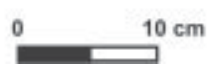

Fig. 4. Skull and mandible osteology of Baurusuchus salgadoensis sp. nov. Holotype MPMA 62-0001-02. (A), (B) Left lateral view; (C), (D) right lateral view; (E), (F) occipital view; (B), (D) and (F) schematic drawings.

bone that borders the inner margins of the supratemporal fenestrae. This bone is located higher than the frontal. As it is very narrow between the two supratemporal fenestrae, it looks like a raised ridge. The supratemporal fenestra is wider than the orbit. The margin in contact with the parietal is convex, while it is straight in the opposite border. They extend beyond the limits of the laterotemporal fenestra, reaching the posterior border of the skull.

The postorbital contacts the frontal, posterior supraorbital, squamosal and parietal. In its anteriormost portion there is a fenestra produced by the contact with the frontal, posterior supraorbital and anterior supraorbital. It contacts the frontal along a straight line. In lateral view it is positioned higher than the posterior supraorbital. At its opposite border the postorbital follows the curvature of the supratemporal fenestra, presenting the same width of the squamosal. The descending process of the postorbital is steeply inclined in the direction of the ascending process of the jugal, resulting in a slightly curved postorbital bar. This is concave, narrow and presents a columnar shape.

The squamosal in dorsal view is V-shaped. It contacts the postorbital, parietal and supraoccipital. Laterally it contacts the quadratojugal and the quadrate. It borders posteriorly the supratemporal fenestra, expands downwards, overhanging the external ear regions and contacts the anterior surface of the paraoccipital process. The angle between the longitudinal axis of the skull roof (squamosal) and the quadrate is $60^{\circ}$.

The quadratojugal is an elongated straight bone, with an ascending process that delimits the posterior border of the quadrangular-shaped laterotemporal fenestra. It contacts the jugal, postorbital, quadrate and squamosal. The quadrate is highly inclined, with two terminal condyles that extend beyond the level of the occipital condyle. It contacts quadratojugal, squamosal, basisphenoid and paraoccipital process. The condylar surface faces posteroventrally.

The supraoccipital is a rhomboid-shaped bone that contacts the parietal, squamosals and exoccipitals. It presents a dorsomedial projection that attains the cranial roof and separates its posterior margin from the parietal. The exoccipitals limit the upper margin of the foramen 
magnum. They extend laterally into the paroccipital processes, which contact the quadrates. There is a large, rounded occipital condyle bordering the ventral margin of the foramen magnum.

The basioccipital is located ventrally to the occipital condyle, comprising a narrow tuberosity that extends laterally and is preceded by the basisphenoid. The basisphenoid is a narrow bone bordering posteriorly the internal nares and pterygoids. The pterygoids form a large plate behind the internal nares. They are expanded laterally forming the lateral pterygoid flanges. Anteriorly are the expansions of the ectopterygoids.

The palatines are in contact along the midline. They are tubular-shaped and contact the maxilla anteriorly and the pterygoids posteriorly. They border two elongated palatal fenestrae that extend from the ectopterygoid to the rear margin of the maxilla.

\section{Mandible}

The mandible is still in articulation with the skull. It is completely preserved on the left side, the right angular and articular are lacking. It is high, slightly projected forwards and anteriorly expanded. The splenials take part in the mandibular symphysis. The mandible outline in lateral view is straight, showing almost the same height along its length, excepting a slight elevation in the dorsal margin of mandibular fenestra region. It is less sculptured than the skull roof.

The dentary makes up the greatest portion of the mandibular length. It comprises ten teeth. Its length is more than half the lower jaw. Its anteriormost part is flattened and bears six conical teeth, surpassed by the premaxilla. The first tooth is projected outwards and presents finely longitudinal striae. The second and third teeth are very small and are disposed laterally in relation to the third upper premaxillary tooth. The fourth dentary tooth is the largest mandibular one. It fits in a clavate notch of the rostrum at the premaxilla-maxilla contact (Fig. 5C, D). Only the right fourth tooth is preserved, while on the left side it is possible to recognize its rounded transverse section through the corresponding alveolus. Two very small teeth follow. Posteriorly, the dentary presents a constriction at the level of the third maxillary tooth and becomes vertical and compressed. There are four more conical teeth of different size, the last two $\left(9^{\text {th }}\right.$ and $10^{\text {th }}$ ) are the largest. The dentary extends as far as the mandibular fenestra. The symphysis is long and extends as far as the level of the fourth maxillary tooth, or the eight dentary tooth. The splenials participate in the mandibular symphysis. Few dentary teeth present carinae with some kind of serrations. Serrations have only been observed in the left $10^{\text {th }}$ (posterior border), right $4^{\text {th }}$ (anterior border) and right $9^{\text {th }}$ (anterior border).
The splenial is a large and vertically positioned bone. It covers the inner surface of the mandibular ramus from the alveolar border to the lower edge of the dentaries. Posteriorly the splenials border the anterior margins of the mandibular fenestrae.

The angular limits the dentary in its anterior portion and posteriorly the surangular and articular. It delimits the lower margin of the mandibular fenestra. This fenestra is very large, located in the same direction of the orbit and of the laterotemporal fenestra, although its rear margin extends beyond the posterior margin of the laterotemporal fenestra. Anteriorly it is aligned with the orbit. The angular is very elongated with the lower and upper borders nearly parallel to the jaw margins. Posteriorly it is very straight, with a slight prominence that forms the postarticular process. Only the left angular is preserved.

The surangular is slightly convex longitudinally. It makes part of the upper margin of the mandibular fenestra, bordering the dentary, angular and articular. The suture with the angular is very straight. As the mandibular fenestra is very large, the bone is relatively narrow in this area. Both surangulars are preserved.

The left articular is almost complete. Its inner surface presents two distinct fossae for articulation of the quadrate condyles. There is a large retroarticular process that is aligned with the upper margin of the surangular. Its medial border is concave.

\section{The Baurusuchidae}

The family 'Baurusuchidae' was defined by Price (1945) as crocodilians with an elongate, laterally compressed skull. The quadrates are vertical and the secondary palate is of mesosuchian type. The dentition is differentiated, with a tendency to an extreme reduction (especially in the maxilla), and with ziphodont teeth. Ectopterygoids are large and make part of the borders of the internal narial openings.

The species that allowed the establishment of this family was Baurusuchus pachecoi Price, 1945 (Figs. 6, 7). Its skull exhibits dermal bones ornamented with irregular ridges. This species presents a long, high and laterally compressed rostrum. The quadrates are directed perpendicularly downwards and a little posteriorly. The external narial opening is single and terminal, and there is no antorbital fenestra. The orbits are laterally directed. The laterotemporal fenestra is separated from the orbit by a thin unsculptured and only slightly depressed postorbital bar. The quadrate is fixed, the supratemporal fenestra being large, longer than wide, and nearly the size of the orbit. The nasals extend anteriorly to the external narial opening. The mandible is heavy, high and with a strong 


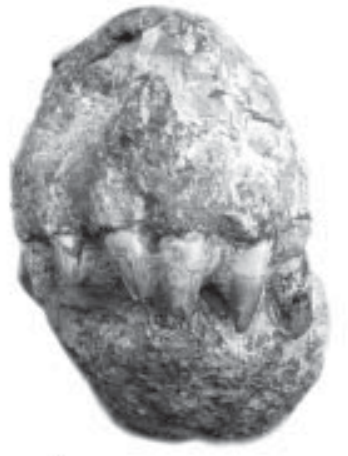

A

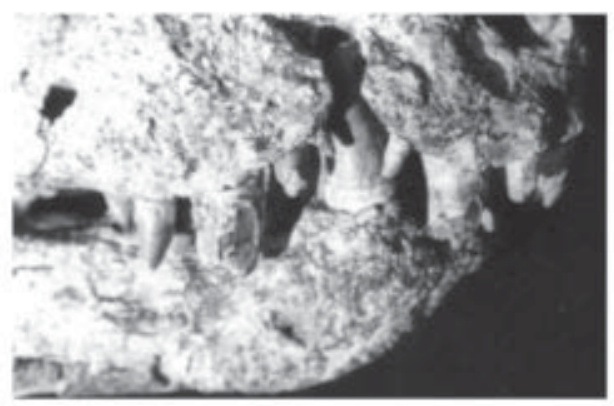

C

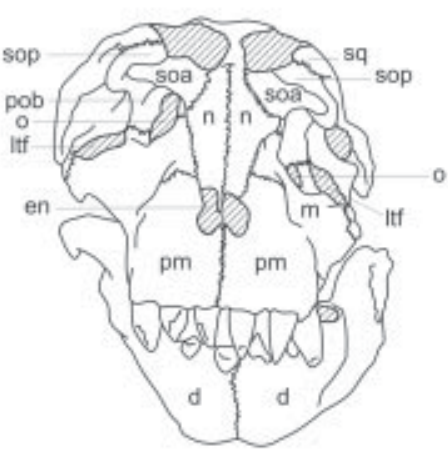

B
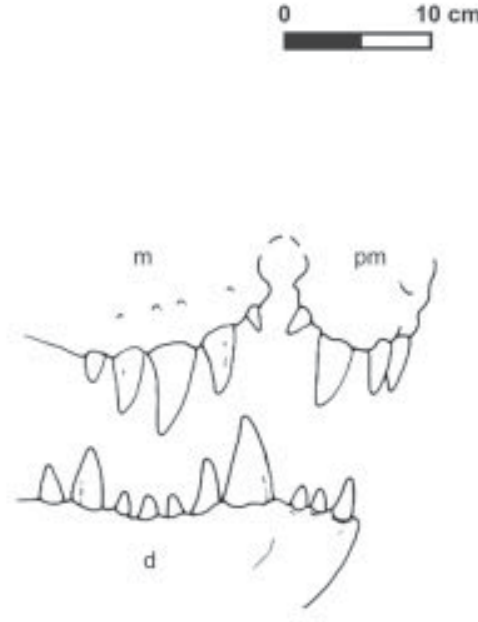

D

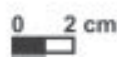

Fig. 5. Detail of the anteriormost region of skull and mandible. Holotype MPMA 62-0001-02. (A), (B) Frontal view of the rostrum anteriormost portion; (C), (D) right lateral view of the rostrum, in occlusion (C) and with the mouth open (D). symphysis, in which the splenials take part. There is a large mandibular fenestra between the angular, surangular and dentary. The retroarticular process is strong and expands mesially (Price, 1945). Between the premaxilla and the maxilla there is a deep clavate-shaped reentrant which receives a large mandibular caniniform ( $4^{\text {th }}$ dentary tooth). According Riff and Kellner (2001) the premaxilla is provided with four teeth, the third one being the largest. In the maxillary there are five teeth, the $3^{\text {rd }}$ maxillary tooth is the largest. In the mandible, the dentary presents ten teeth. The $4^{\text {th }}$ dentary tooth has an elliptical transverse section. During occlusion this tooth is positioned in a diastema between the last premaxillary and the first maxillary tooth, in a deep clavate-shaped reentrace between the premaxilla and the maxilla. All teeth present a ziphodont condition: they are laterally compressed and have serrated carinae.

The new taxon - Baurusuchus salgadoensis - differs from Baurusuchus pachecoi by the more straight posterior skull border, the parietals forming a ridge between the two supratemporal fenestra, the double external nares with a bone septum, the presence of an antorbital fenestra, two well-fused supraorbitals (palpebral bones), an elliptical orbit, the posterior border of nasals and prefrontal higher than the frontal, the supratemporal fenestrae larger than the orbit and the quadrangular laterotemporal fenestra. Other aspects are the more rounded and less crenulated teeth of Baurusuchus salgadoensis. As has been shown through the study of the ziphodont teeth from India (Prasad and Broin, 2002) it is possible that the differences among these kind of teeth are indicative of taxonomic differences. The skull roof of Baurusuchus pachecoi is higher and rounded posteriorly, while in Baurusuchus salgadoensis it is more straight. In Baurusuchus pachecoi the quadrate and the occipitals are more vertically oriented than in Baurusuchus salgadoensis. Also in this last species the posterior margins of nasals and prefrontals are higher in relation to the more depressed frontal. The parietals are also more elevated than the frontal and developed a ridge between the two large supratemporal fenestra. These are larger than the orbit, an aspect not observed in Baurusuchus pachecoi. A striking feature of Baurusuchus salgadoensis is the presence of a large antorbital fenestra located in maxilla and lacrimal. Antunes (1967a, b) and 
Witmer (1997) considered that this aspect is a primitive archosaurian condition, frequent in basal crocodylomorphs. Therefore, this structure was not observed in other Baurusuchidae, with the exception of Bergisuchus dietrichbergi from the Eocene of Messel (Germany) as observed by Buffetaut (1982b). The supraorbitals of Baurusuchus salgadoensis are also very peculiar. Each orbit is protected by an anterior and a posterior well-prominent supraorbital. The posterior supraorbital is thicker and more projected than the anterior one. In their contact area they developed an elliptical fenestra not observed in any other baurusuchian crocodyliform. The external nares of Baurusuchus salgadoensis show a thin bone septum that divides the nares in two separated cavities. In the mandible it is also possible to observe a distinction in the mandibular fenestra shape. It is elliptical, with a rear upper margin positioned upward in Baurusuchus pachecoi, while in Baurusuchus salgadoensis their upper and lower margins are parallel to the surangular and angular external borders.

Another Brazilian Baurusuchidae is Stratiotosuchus maxhechti Campos, Suarez, Riff and Kellner, 2001 (Fig. 7C). The dermal bones of the skull are heavily ornamented with irregular ridges. The anterior region of the skull is high. The orbit has a rectangular shape. The supratemporal fenestra is large and pear-shaped. The lateral temporal fenestra is subtriangular and is smaller than the supratemporal fenestra. The external nares are dorsoanteriorly located in a depressed area of premaxillae and are separated from each other by a small bony septum. The premaxilla is a short bone that bears three ziphodont

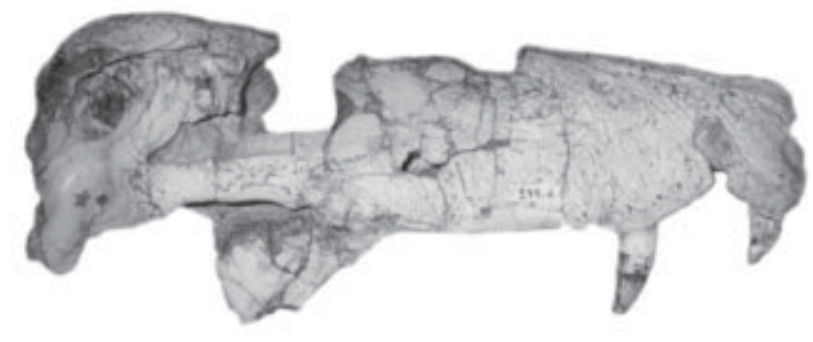

A

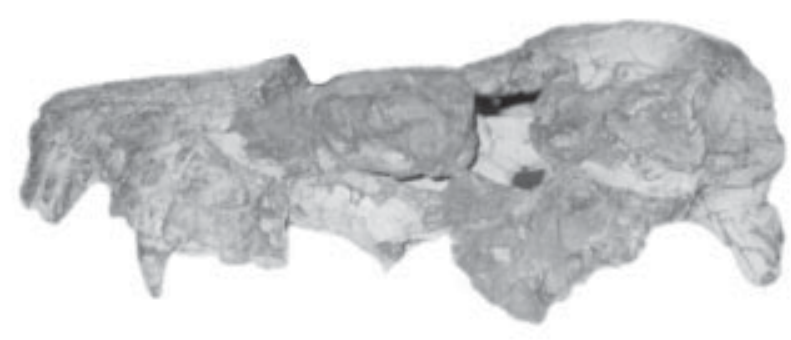

B teeth. On the contact with the maxilla, both bones form an opening that receives a large caniniform dentary tooth. The maxilla has a rectangular shape with the lateral surface essentially vertical, forming most of the lateral part of the rostrum. The dorsolateral portion of this bone is very thick making the skull of Stratiotosuchus larger than that of Baurusuchus. There are five maxillary alveoli. The nasal is long and makes the posterior border of the external nares. The sutures with the frontal have a V-shaped form. The lacrimal is subtriangular, slightly concave, and forms the anterior and anterodorsal border of the orbit. The prefrontal forms the posterodorsal border of the orbit and is trapezoidal in shape. Posterior to this bone, there is possibly the postorbital, which forms the lateroanterior margin of the supratemporal fenestra. The jugal is robust, with a well-marked lateral flange, extending anteriorly well before the orbit. The frontals are fused and form a wide plate with a depressed area on its posterior portion. The contact with the parietal is straight, this bone is narrow and has two developed central ridges between the supratemporal fenestra. The quadratojugal is elongated and is part of the posterior margin of the latero-temporal fenestra. The quadrate is posteroventrally directed and shows a pronounced groove (Campos et al., 2001).

In Argentina, a Cretaceous baurusuchid is known, Cynodontosuchus rothi Woodward, 1896 (Fig. 7D) from the Neuquén Group (Pichi Picún Leufú Formation, Coniacian-Santonian, Paso del Sapo locality). This species is based on a partial rostrum. The rostrum of Cynodontosuchus

Fig. 6. Baurusuchus pachecoi. Skull right (A) and left (B) lateral views. Mandible in dorsal view (C). Specimen DGM 299-R (Holotype). 
is less high than that of Baurusuchus and shows five maxillary teeth (Woodward, 1896, Buffetaut, 1982 b), with a very large maxillary caniniform (Steel, 1973). There are probably three small circular section teeth in the premaxilla. There is an interalveolar diastema between the first and the second teeth where the first mandibular tooth fits. The external surface of maxilla is vertical and it shows five teeth. The first one is the smallest, the second is the largest, with a curved crown that reaches the inferior border of the mandibular symphysis. Its root extends up to the limit of the maxillary-nasal suture. The tooth series is completed with three laterally compressed teeth of progressively smaller size. The nasals are only preserved in part. The external nares were probably in a terminal or almost terminal position. The anterior portion of the palate is formed by the maxillae, the palatines are two cylindrical bars located at the medium line of the palate. In the middle of each one there is a conduit that is the narial channel, similar as those of the other Baurusuchidae. The mandible shows two vertical mandibular rami. In the mandibular symphysis there are two distinct portions: the posterior one is short and flattened, while the anterior portion is expanded and vertically developed towards the premaxillae. In the anterior portion of the mandible there is a small tooth that fits between the first and the second teeth of the premaxilla. There is also an hypertrophied mandibular tooth (probably the $4^{\text {th }}$ ) that fits in a diastema between the premaxillary and the maxillary (Gasparini, 1972). The anterior part of the mandibular rami is slightly divergent and the symphysis is nearly twice as long as wide (Steel, 1973). Cynodontosuchus is probably cogeneric with the Brazilian Baurusuchus (Gasparini, 1996).

There are also a Cretaceous baurusuchid and possible Tertiary baurusuchians outside the South American region (Kuhn, 1968; Steel, 1973; Antunes, 1975, 1986; Buffetaut, 1980a, 1982a, b, c; Ortega et al., 1996; Wilson et al., 2001).

The Cretaceous species is Pabwehshi pakistanensis Wilson, Malkane and Gingerich (2001) from Pakistan (Pab Formation, Maastrichtian, Balochistan Province). The species is known through a snout and an anterior portion of left and right mandibular rami fused at the symphysis. Pabwehshi pakistanensis is a medium-sized baurusuchid, with a reduced anterior portion of the rostrum retaining three premaxillary teeth. It is characterized by autapomorphies such as: a dorsally inset first premaxillary alveolus, a prominent premaxillary lip overhanging the external nares, a diverticulum in the posterodorsal corner of the external naris, an enlarged, caniniform sixth dentary tooth, reduced fourth and fifth dentary teeth, and a diastematic fossa positioned just posterior to the second maxillary tooth (Wilson et al., 2001).

The Tertiary baurusuchids are found in Europe. Two species were included in this family: Bergisuchus dietrichbergi Kuhn, 1968 (Lutetian, Messel, Germany) and Iberosuchus macrodon Antunes, 1975 (Feligueira Grande Formation, Eocene, Portugal). Bergisuchus dietrichbergi is known by a fragment of a rostrum and a mandible. It is possible to observe an antorbital fenestra. There are probably eight maxillary teeth and seven dentary teeth (Berg, 1966, Buffetaut, 1982 b). The baurusuchid Iberosuchus macrodon from Portugal presents a very high snout, enlarged in its premaxillary area, a forward nasal opening and laterally compressed teeth with serrated edges. There is also a big notch between the premaxilla and maxilla in correspondence to a large $4^{\text {th }}$ dentary tooth (Antunes, 1975). Other possible European baurusuchids are the specimens of Spain (Caenes, Middle Eocene, Duero Basin) and France (Issel, Middle Eocene) identified by Ortega et al. (1996) as cf. Iberosuchus. The French specimen was named before as Atacisaurus crassiproratus Astre, 1931. In Africa occurs Eremosuchus elkoholicus Buffetaut, 1989 (Eocene, El Kohol - Algeria), which has been considered as closely related to Baurusuchus (Buffetaut, 1982a, c). In a more detailed comparison between Eremosuchus and Baurusuchus, Buffetaut (1989) considered that they are not related genera, and identified Eremosuchus as a Trematochampsidae. Despite this, in the phylogenetic study of Ortega et al. (1996) a closer relationship is presented between Eremosuchus, Baurusuchus, cf. Iberosuchus and Sebecus, which were grouped in a clade (Sebecosuchia), whereas the remaining trematochampsids were placed in different phylogenetic contexts. The genus Eremosuchus presents, as Baurusuchus, a very pronounced sigmoidal tooth row that contrasts with the semi straight ventral edge of the dentary. It has an autapomorphy - a constricted base of the tooth crown (Ortega et al., 1996). Eremosuchus presents a remarkably deep and laterally compressed dentary with a marked concavity in its lateral surface. It bears 12 alveoli arranged in a sinuous row, the fourth alveolous being the largest. The dentary symphysis reached the level of the fifth alveolous, and splenials apparently also took part in the symphysis. The surangular takes part in the jaw articulation. The teeth are laterally compressed and bear two sharp, finely serrated carinae (Buffetaut, 1982 a, 1989).

\section{Phylogeny of Baurusuchidae}

The name Metasuchia was erected by Benton and Clark (1988) for a group comprising non-thalatosuchian mesoeucrocodilians, mainly the terrestrial crocodylomorphs from Gondwana. They considered two hypotheses of relationships for primitive metasuchians. The first one, a less parsimonious hypothesis, considered Bauruchus and Sebecus as a clade (the Sebecosuchia). However, as there is a substantial number of conflicting characters, they 

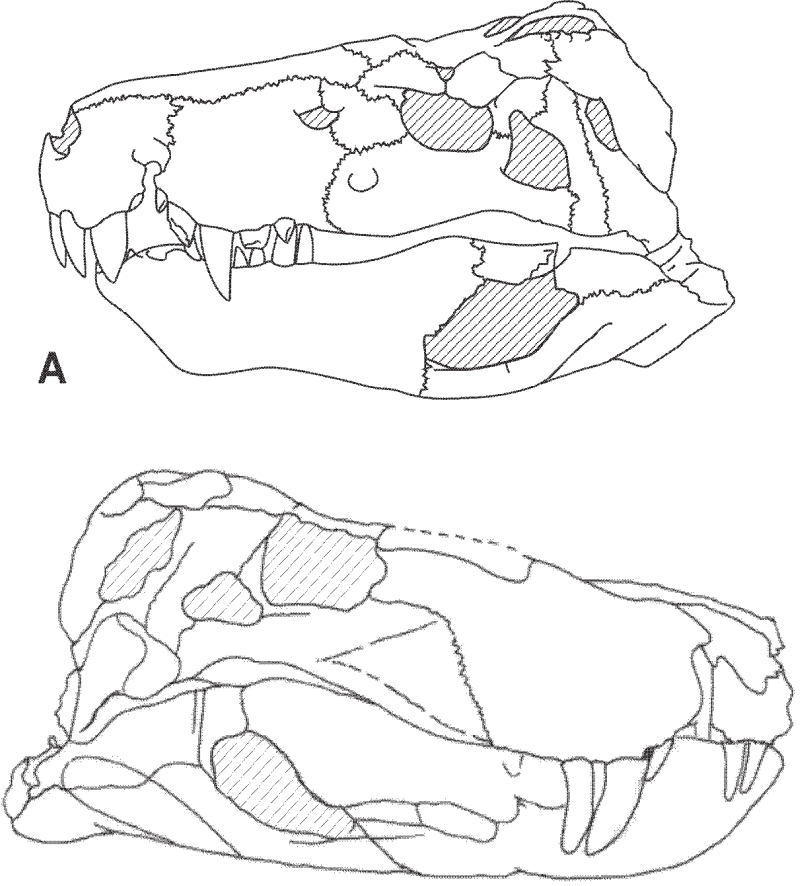

B

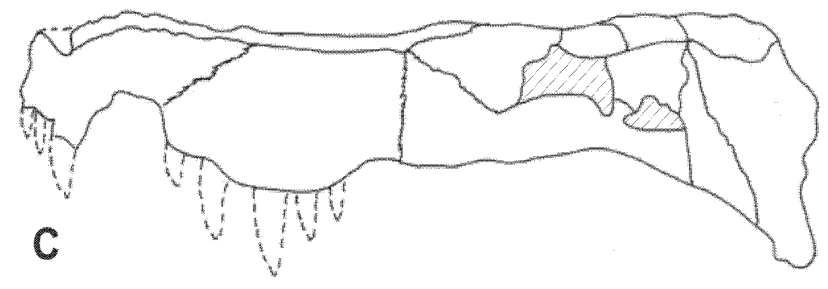

Stratiotosuchus maxhechti

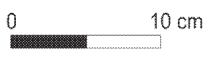

Cynodontosuchus rothi

Baurusuchus salgadoensis

Baurusuchus pachecoi

Pabwehshi pakistanensis

$\mathbf{E}$

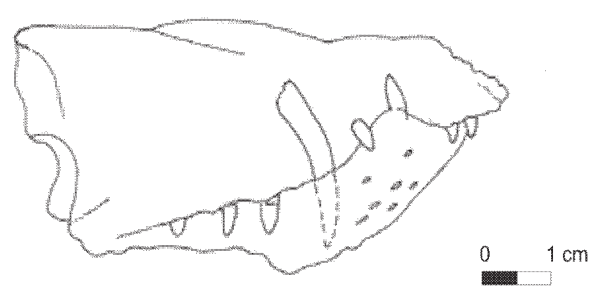

D

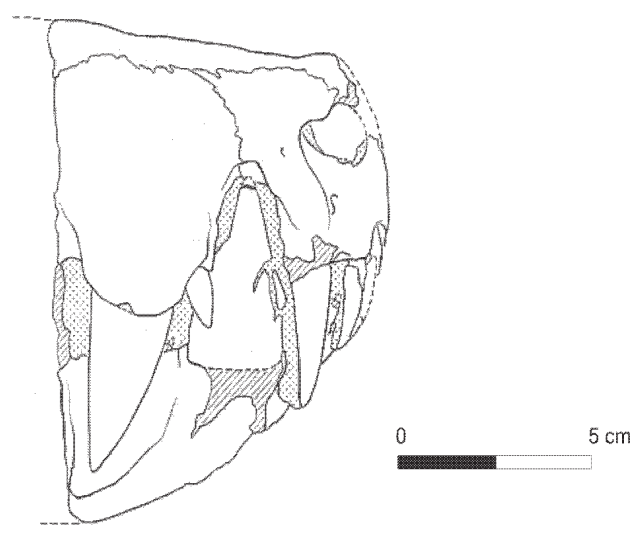

Fig. 7. Skull morphology of baurusuchids. (A) Baurusuchus salgadoensis; (B) Baurusuchus pachecoi (modified from Price, 1945); (C) Stratiotosuchus maxhechti (modified from Campos et al., 2001); (D) Cynodontosuchus rothi (after Gasparini, 1972); (E) Pabwehshi pakistanensis (modified from Wilson et al., 2001). 
suggested a second hypothesis: Sebecus would be closer to the Neosuchia (which includes eusuchians), comprising a clade, and Baurusuchus would be included in another one. The idea of Sebecosuchia as a polyphyletic group was reinforced by Clark (1997), but it was not followed by other researchers. Gomani (1997) discussed the relationships of Malawisuchus (Mwakasyunguti, Malawi, Early Cretaceous) with the primitive metasuchians Notosuchus, Uruguaysuchus, Araripesuchus, Sebecus, Baurusuchus, Libycosuchus, the "Fruita Form", Candidodon and Chimaerasuchus. The cladistic analysis showed that Malawisuchus, Candidodon and Chimaerasuchus compose a clade and reinforces the proposal of Gasparini et al., (1991) that Baurusuchus and Sebecus form another clade. This same pattern is shown in the phylogenetic analyses (Buckley and Brochu,1999, Buckley et al., 2000) of Mahajangasuchus and Simosuchus, both from the Maevarano Formation (Mahajanga Basin, Madagascar, Upper Cretaceous). The phylogenetic analysis of Calsoyasuchus, a Jurassic Goniopholidae from the Kayenta Formation, U.S.A., presented by Tykoski et al., (2002), also shows Baurusuchus and Sebecus as a clade.

In the study of Gasparini et al., (1991), the Sebecosuchia (Sebecus icaeorhinus Simpson, 1937+Baurusuchus pachecoi Price, 1945) was considered a monophyletic group, supported by the following synapomorphies: laterally compressed rostrum, absence of antorbital fenestra, internal nares very large, a strongly concave palate, and vertical pterygoids. Even when other Tertiary sebecosuchians are included such as Bretesuchus bonapartei Gasparini, Fernandez and Powell, 1993 and Sebecus huilensis Langston, 1965 the group still remains monophyletic (Gasparini et al., 1993). The character analysis of European (cf. Iberosuchus) and African (Eremosuchus) sebecosuchians presented by Ortega et al. (1996) established a clade (the traditional Sebecosuchia) which besides Baurusuchus and Sebecus also included cf. Iberosuchus and Eremosuchus. The genera Baurusuchus +Eremosuchus are the sister group of cf. Iberosuchus. All of these present a longitudinal depression on the dentary that forms a deep fossa around the mandibular fenestra. In Sebecus and Baurusuchus the fossa is extended on the surangular and the angular, but cannot be observed in the other two genera due to the preservation conditions (Ortega et al., 1996).

The phylogenetic proposal for basal mesoeucrocodylians of Pol (1999) considered that Notosuchia is not a monophyletic group and proposed a clade that includes them and Baurusuchus. This author considered that Baurusuchus has the notosuchian synapomorphies and shares several derived characters that define its position nested within the Notosuchia.

Ortega et al. (2000) in the study of Araripesuchus patagonicus defined Ziphosuchia as a taxon that involves
Notosuchus +Libycosuchus +Sebecosuchia. The derived conditions of the characters of Araripesuchus + Neosuchia are not shared by any of the other basal mesoeucrocodylians such as Baurusuchus, Sebecus, Bretesuchus, Libycosuchus and Iberosuchus (which are members of Ziphosuchia). This idea was not supported by Larsson and Gado (2000) who included Notosuchus +Araripesuchus + Libycosuchus + Baurusuchus +Sebecus as a clade.

Carvalho et al. (2004) established a new taxon to include the Baurusuchidae. It was named Baurusuchoidea and includes the most recent common ancestor of Sebecus and the Baurusuchidae and all of their descendants. It was considered a monophyletic taxon, supported by synapomorphies such as: distance from the anterior orbital edge to the anterior contour of rostrum at least twice than the distance from anterior orbital edge to posterior parietal limit, presence of a premaxillo-maxillary notch, the last premaxillary alveolus is not the largest of premaxillary tooth row, teeth are disposed in isolated alveoli, caudal branch of quadrate being at least as long as broad, enlarged second or third alveolus of maxilla, skull roof square or rectangular and with a longitudinal dominant axis, lateral surface of jugal not visible in ventral view, straight jugal. Then, the Baurusuchidae Price, 1945 were redefined as the most recent common ancestor of Baurusuchus and Stratiotosuchus and all of their descendants. The members of this taxon possess the following synapomorphies: presence of a foramen at premaxillo-maxillary suture in lateral view, basisphenoid widely exposed in ventral view, infratemporal fenestrae much longer than deep, post-caniniform dentary teeth with waves of size variation, sigmoidal outline of dentary tooth row in dorsal view, septated internal nares, less than ten maxillary teeth.

\section{Palaeoecology and Palaeogeography}

Baurusuchus salgadoensis was a terrestrial crocodyliform. As observed by Ralph Molnar (pers. comm., 2004) the position of the external nares, located on anterior and terminal portion of the rostrum together with the theropod-like lateral compression of the snout and teeth are indicators of a terrestrial adaptation. Therefore some Metriorhynchidae - exclusively marine crocodylomorphs - also present such aspects, except for the nares that are not so terminal as in Baurusuchus (Zulma Gasparini, 2004, pers. comm.). This was a carnivorous species and the lateral compression of the Baurusuchus salgadoensis rostrum could be interpreted, like other Baurusuchidae (Buffetaut, 1982b), as a mechanism to increase the skull resistance forces during biting (Fig. 8). The pointed, conical teeth with crenulated borders could be used to penetrate and to slice the prey. 
Despite some interpretations of sebecosuchians (which include the Baurusuchidae) as living near banks of rivers, spending part of their life in the water and part on land (Colbert, 1946), the morphological aspects such as the lateral compression of the snout, the ziphodont teeth, the almost lateral orbits, the particular jaw muscles, the strong femur with a well developed fourth trochanter, allowed them, as predators, to be more terrestrial than other crocodilians (Gasparini et al., 1993). Also adaptative characters, such as the strongly bent pterygoids, which allow a greater pterygoid muscle attachment, appropriate to close the mouth rapidly with a powerful bite. Baurusuchids probably played an important role as active predators, competing with the theropods, such as the abelisaurids (Gasparini et al., 1993).

Due the similarities of skull morphology and the bladed teeth, Busbey III (1986) considered that the foraging strategy used by the sebecosuchians should be similar to the modern reptile Varanus komodensis. The cranial morphology of ziphodont crocodilians, such as the one of Baurusuchus salgadoensis, indicate that prey acquisition and manipulation occurred on land. As Varanus the animal could wait along frequently traveled paths for passing prey, attacking it when at close distance. Busbey III (1986) suggested that the predator lunges out, bites the prey, and pulls back, slicing through the prey with its flattened, serrated teeth. This feeding behavior minimizes torque on the rostrum, resulting from prey struggle, and maximizes resistance to the compression forces along the sides of the skull.

The environment were Baurusuchus salgadoensis lived can be inferred from stratigraphic indicators and ecological aspects of extant crocodilians. Baurusuchus salgadoensis was found in a succession of fine massive sandstones, with tabular geometry, intensely bioturbated. The sequence was interpreted as a floodplain area of a braided river in a seasonally hot and arid climate. Living crocodilians are climatically controlled by a mean annual temperature equal or more than $14.2^{\circ} \mathrm{C}$, although local hydrological conditions play an important role, providing a buffer effect against temperature extremes (Markwick, 1998). There are some divergent data concerning the occurrence of Baurusuchus salgadoensis and the possible climatic context in which they lived. Markwick (1998) has shown that the continentality, expressed by seasonality and increased aridity, is a limiting factor to the distribution of the crocodilians. Despite this, Baurusuchus salgadoensis, the unique vertebrate fossil identified until now in the area, probably lived in a hot and arid climate. The occurrence of almost complete articulated skeletons in nearby correlated stratigraphic levels suggests they could dig large, deep burrows in soft substrates that allowed, like living alligators, thermoregulation. These excavated holes provide a source of water during dry periods. This ethological aspect probably allowed them to live in more terrestrial and arid environments.

Based on the distribution data presented by Buckley and Brochu (1996, 1997, 1999), Gasparini et al. (1991), Larsson and Gado (2000) and Ortega et al. (2000) of the South American and African crocodylomorphs, Carvalho et al. (2004) considered it premature to point an endemism of the Late Cretaceous Bauru crocodylomorphs as suggested by Bertini (1993) until a better understanding of the faunal distribution between South America and Africa is reached.

The baurusuchids as other Sebecosuchia (Langston Jr., 1956) were probably cosmopolitan crocodylomorphs, although Gasparini et al. (1991) have showed that the Late Cretaceous continental crocodilians of South America are mainly composed by "mesosuchian" types, while in the northern continents the eusuchians dominate.

According to Buffetaut (1980b, 1982b, c), the palaeobiogeography of baurusuchids shows a diversification history before the South America-Africa separation, during the Early Cretaceous. The origin of this group probably occurred in South America and later in the Tertiary (Eocene) it reached Europe through a North American route. Antunes (1975) suggested that the Eocene baurusuchids in Europe were immigrants from South America, their main area of radiation. They probably passed into North America and Europe, then linked by Greenland, during the Paleocene.

A very different hypothesis is presented by Buffetaut (1982 a). It is based on a ziphodont mesosuchian crocodyliform from the Eocene of Algeria (Eremosuchus elkoholicus Buffetaut, 1989) and the paleobiogeographical proposals of Mourer-Chauviré $(1981,1982)$ and Rage (1981) that indicate that this fossil could be the first evidence that some of these land vertebrates may have reached Europe from Africa, after differentiating in Gondwana, either before or after South America became separated from Africa. This proposal is in accordance with the paleoceanographical reconstructions of the South Atlantic presented by Azevedo (2001) and Dias-Brito $(1995,2002)$ and the paleobiogeographical reconstructions of Buffetaut and Taquet (1979) and Calvo and Salgado (1996). It considers valid the hypothesis of Rage (1981) of a land connection through the Walvis-Rio Grande rises, which were probably episodically subaerial in the Late Cretaceous, allowing the interchange of the terrestrial biota between South America and Africa.

However, as Cretaceous baurusuchids are, until now, unknown from Africa, another paleobiogeographical possibility was evoked by the discovery of Pabwehshi 


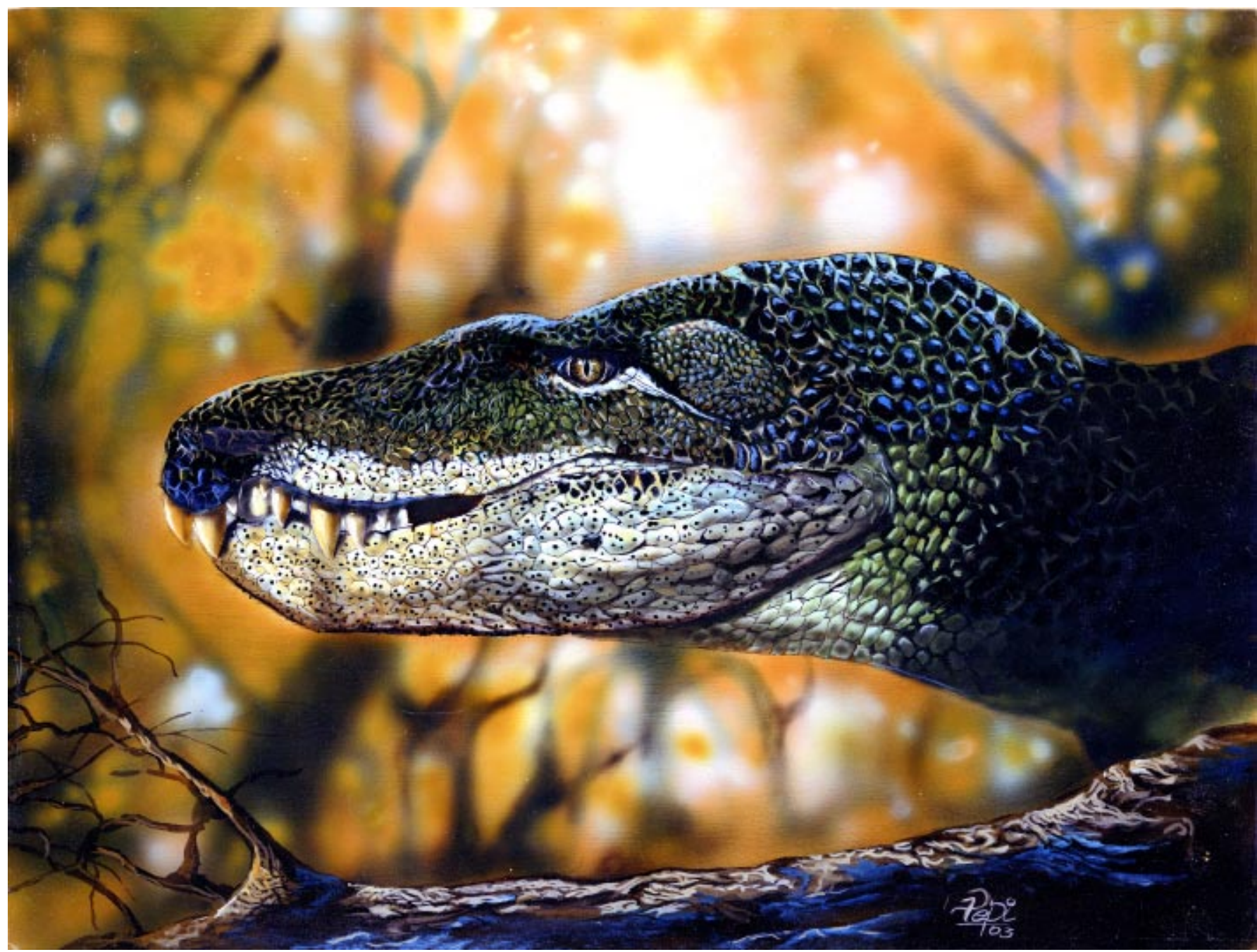

Fig. 8. Restoration of Baurusuchus salgadoensis sp. nov. (art by Deverson da Silva).

pakistanensis, from Pakistan. According to Wilson et al. (2001) an Early Cretaceous, or even a Late Cretaceous Gondwanic 'terrestrial route' between South America and Indo-Pakistan via Antarctica, would explain the presence of this group in Asia. Later, during the Paleogene, their dispersion through Eurasia allowed them to reach North Africa and Iberia. This is an alternative and plausible 'land corridor' to the classic South America-Africa connection.

\section{Legend}

af - antorbital fenestra

ang - angular

art - articular

bo - basioccipital

bs - basisphenoid

d - dentary ec - ectopterygoid

en - external nares

exo - exoccipital

f - frontal

fm - foramen magnum

in - internal nares

j - jugal

jrd - jugal rounded depression

1 - lacrimal

lpf - lateral pterygoid flange

ltf - laterotemporal fenestra

m - maxilla

mf - mandibular fenestra

$\mathrm{n}$ - nasal

o - orbit

oc - occipital condyle

occ - occipital

$\mathrm{p}$ - parietal 
pf - prefrontal

$\mathrm{pl}$ - palatine

pm - premaxilla

po - postorbital

pt - pterygoid

paf - palatal fenestra

pap - postarticular process

pob - postorbital bar

q - quadrate

qj - quadratojugal

sa - surangular

soa - anterior supraorbital

sop - posterior supraorbital

soc - supraoccipital

sof - supraorbital foramen

sp - splenial

sq - squamosal

stf - supratemporal fenestra

\section{Acknowledgments}

Thanks are due to Professor João Tadeu Arruda and Professor Júlio Cesar Paulino (General Salgado, São Paulo State) who collaborated in the excavation of the specimen, and to Mr. Sílvio Cardoso who facilitated the access to the excavation area located in his property. The fossil analysed in this study was prepared in the laboratory by Sandra Aparecida Simionato Tavares, Cledinei Aparecido Francisco, Antonio Eduardo Justino Leite and Thiago Schneider Fachini. The drawings presented in this paper were prepared by Deverson da Silva, Luiz Antonio Sampaio Ferro (UFRJ), and José Duarte Correia (IBGE). Critical reviews by Professor Zulma Gasparini (Museo de la Plata, Argentina), Professor Ralph Molnar (Museum of Northern Arizona, USA), Professor Miguel Telles Antunes (Universidade Nova de Lisboa, Portugal) and Professor Rudolph A.I. Trouw (Universidade Federal do Rio de Janeiro, Brazil) improved the manuscript. We thank the financial support provided by Prefeitura Municipal de Monte Alto, Instituto Virtual de Paleontologia/Fundação Carlos Chagas Filho de Amparo à Pesquisa do Estado do Rio de Janeiro (FAPERJ), Conselho Nacional de Desenvolvimento Científico e Tecnológico (CNPq, grant n ${ }^{\circ}$ 300571/03-8) and Fundação Universitária José Bonifácio (FUJB-UFRJ).

\section{References}

Alves, J.M.P.and Ribeiro, D.T.P. (1999) Evolução diagenética das rochas da Formação Marília - Minas Gerais, Brasil. In: Simp. Sobre o Cretáceo do Brasil, 5, 1999. Bol., Serra Negra, UNESP, pp. 327-332.

Andreis, R.R., Capilla, R. and Reis, C.C. (1999) Considerações estratigráficas e composição dos arenitos da Formação Marília (Cretáceo Superior) na região de Uberaba (MG). In: Simp. Sobre o Cretáceo do Brasil, 5, 1999. Bol., Serra Negra, UNESP, pp. 449-455.

Antunes, M.T. (1967a) Un mesosuquiano do Liásico de Tomar (Portugal). Considerações sobre a origem dos crocodilos. Direção Geral de Minas e Serviços Geol., Mem. n 13 (Nova Série), 66p.

Antunes, M.T. (1967b) Sur quelques caractères archaïques des Crocodiliens, à propos d'un Mésosuchien du Lias supérieur de Tomar (Portugal). Remarques sur l"origine des Crocodilia. In: Colloques International C.N.R.S., Paris, $\mathrm{n}^{\circ}$ 163, Problèmes Actuels de Paléontologie (evolution des vertébrés), pp. 409-414.

Antunes, M.T. (1975) Iberosuchus, crocodile Sebecosuchien nouveau, l'Eocène ibérique au Nord de la Chaìne Centrale, et al.l'origine du canyon de Nazaré. Com. dos Serviços Geol. Portugal, v. 59, pp. 285-330.

Antunes, M.T. (1986) Iberosuchus et Pristichampsus, crocodiliens de l'Éocène. Données complémentaires, discussion, distribution stratigraphique. Ciências da Terra, v. 8, pp. 111-122.

Arid, F.M. and Vizzoto, L.D. (1965) Crocodilídeos fósseis nas proximidades de Santa Adélia (SP). Ciência e Cultura, v. 17, pp. 138-139.

Arid, F.M. and Vizzoto, L.D. (1971) Traços paleogeográficos e paleobiológicos do Cretáceo Superior da região norteocidental do Estado de São Paulo. Ciência e Cultura, v. 23, pp. 229-236.

Azevedo, R.M.L. (2001) O Albiano no Atlântico Sul: estratigrafia, paleoceanografia e relações globais. Prog. Pós-Graduação em Geociências, Univ. Federal do Rio Grande do Sul, DSc. Thesis, v. 1, 265p.

Azevedo, S.A.K. and Campos, D.A. (1993) Um novo crocodilídio (Mesosuchia) do Cretáceo de Minas Gerais, Brasil. Anais da Acad. Brasil. Ciências, v. 65, pp. 460.

Baez, A.M. and Peri, S. (1989) Baurubatrachus pricei nov.gen. et sp., un anuro del Cretacico Superior de Minas Gerais, Brasil. Anais da Acad. Brasil. Ciências, v. 61, pp. 447-458.

Barbosa, O. (1955) Situação geológica das charophyta de Machado de Melo, Estado de São Paulo. Bol. Soc. Brasil. Geol., v. 4, pp. 73-74.

Batezelli, A., Perinotto, J.A.J., Etchebehere, M.L.C., Fulfaro, V.J. and Saad, A.R. (1999) Redefinição litoestratigráfica da unidade Araçatuba e da sua extensão regional na Bacia Bauru, Estado de São Paulo, Brasil. In: Simp. Sobre o Cretáceo do Brasil, 5, 1999. Boletim, Serra Negra, UNESP, pp. 195-200.

Benton, M.J. and Clark, J.M. (1988) Archosaur phylogeny and the relationships of the Crocodylia. In: M. J. Benton (Ed.), The phylogeny and classification of the tetrapods, v.1: Amphibians, reptiles, birds. Systematics Assoc., Clarendon Press, Oxford, pp. 295-338. (Spec. v. no 35 A)

Berg, D.E. (1966) Die Krokodile, insbesondere Asiatosuchus und aff. Sebecus?, aus dem Eozän von Messel bei Darmstadt/ Hessen. Abhandlungen des Hessischen Landesamtes für Bodenforschung, Heft, v. 52, pp. 1-105.

Bertini, R.J. (1993) Paleobiologia do Grupo Bauru, Cretáceo Superior continental da Bacia do Paraná, com ênfase em sua fauna de amniotas. Rio de Janeiro. Prog. Pós-Graduação em Geologia, Univ. Federal do Rio de Janeiro, DSc. Thesis, $397 \mathrm{p}$.

Bertini, R.J. (1994a) Comments on the fossil amniotes from the 
Adamantina and Marília formations, continental Upper Cretaceous of the Paraná Basin, Southeastern Brazil (Part 1: Introduction, Testudines, Lacertilia, Crocodylomorpha). In: Simp. Sobre o Cretáceo do Brasil, 3, 1994. Bol., Rio Claro, UNESP, pp. 97-100.

Bertini, R. J. (1994b) Comments on the fossil amniotes from the Adamantina and Marília formations, continental Upper Cretaceous of the Paraná Basin, Southeastern Brazil (Part 2: Saurischia, Ornithischia, Mammalia, conclusions and final considerations). In: Simp. Sobre o Cretáceo do Brasil, 3, 1994. Bol., Rio Claro, 1994, UNESP, pp. 101-104.

Bertini, R.J. and Carvalho, I.S. (1999) Distribuição cronológica dos crocodilomorfos notossúquios e ocorrências nas bacias cretácicas brasileiras. In: SIMP. SOBRE O CRETÁCEO DO BRASIL, 5, 1999. Serra Negra, UNESP, pp. 517-523.

Bertini, R.J., Manzini, F.F. and Brandt Neto, M. (1999) Novas ocorrências de Baurusuchidae (Sebecosuchia: Crocodylomorpha) na região de General Salgado, Formação Adamantina (Cretáceo Superior) do Grupo Bauru na região Noroeste do Estado de São Paulo. Acta Geol. Leopold., v. 23, pp. 29-38.

Bertini, R.J., Marshall, L.G., Gayet, M. and Brito, P.M. (1993) Vertebrate faunas from the Adamantina and Marília formations (Upper Bauru Group, Late Cretaceous, Brazil) in their stratigraphic and paleobiogeographic context. Neues Jahrbuch für Geol. Paläontol. Abhandlungen, v. 188, pp. 71-101.

Bonaparte, J.F. (1978) El Mesozoico de América del Sur y sus tetrapodes. Opera Lilloana, v. 26, 596 p.

Brandt Neto, M., Manzini, F.F. and Bertini, R.J. (1992) Sobre um membro locomotor dianteiro de Baurusuchidae (Crocodylia), da região de General Salgado (SP). In: Simp. Sobre as Bacias Cretácicas Brasil., 2, 1992. Resumos Expandidos, Rio Claro, UNESP, pp. 163-164.

Brandt Neto, M., Barcha, S. F., Manzini, F.F. and Brighetti, J.M.P. (1991) Nova ocorrência de crocodilianos na região noroeste do Estado de São Paulo. Geociências, UNESP, v. 10, pp. 191-203.

Brandt Neto, M., Bertini, R.J., Manzini, F.F. and Notoya, E.Y. (2001) Evidência de um novo crocodylomorpha "Mesosuchia" no Grupo Bauru, proveniente da região de São José do Rio Preto, Estado de São Paulo. In: Cong. Brasil. Paleontol., 17, 2001. Bol. de Resumos, Rio Branco,UFA, pp. 152.

Buckley, G.A. and Brochu, C.A. (1996) Campanian (Upper Cretaceous) crocodyliforms from Madagascar and their biogeographic implication. J. Vertebrate Paleontol., Abst. of Pap., v. 16, pp. 24.

Buckley, G.A. and Brochu, C.A. (1997) Hyperdiversity and the paleobiogeographic origins of the Late Cretaceous crocodyliforms of Madagascar. J. Vertebrate Paleontol., Abst. of Pap., v. 17, pp. 35.

Buckley, G.A. and Brochu, C.A. (1999) An enigmatic new crocodile from the Upper Cretaceous of Madagascar. Spec. Pap. in Palaeontol., v. 60, pp.149-175.

Buckley, G.A., Brochu, C.A., Krause, D.W. and Pol, D. (2000) A pug-nosed crocodyliform from the Late Cretaceous of Madagascar. Nature, v. 405, pp. 941-944.

Buffetaut, E. (1980a) Crocodilians from the continental Upper Cretaceous of Europe: new finds and interpretations. Mesozoic Vertebrate Life, San Diego, v. 1, pp. 5-14.

Buffetaut, E. (1980b) Histoire biogéographique des Sebecosuchia (Crocodylia, Mesosuchia): un essai d'interprétation. Annales de Paléontol. (Vertébrés), v. 66, pp. 1-18.
Buffetaut, E. (1982a) A ziphodont mesosuchian crocodile from the Eocene of Algeria and its implications for vertebrate dispersal. Nature, v. 300, pp.176-178.

Buffetaut, E. (1982b) Radiation évolutive, paléoécologie et al.biogéographie des crocodiliens mésosuchiens. Mém. Soc. Géol. France, v. 142, pp.1-88.

Buffetaut, E. (1982c) Un problème de paléobiogéographie continentale: les Crocodiliens mésosuchiens ziphodontes de l'Éocène européen. Bull. Soc. Géol. France, v. 24, pp. 1101-1107.

Buffetaut, E. (1985) Prèsence de Trematochampsidae (Crocodylia, Mesosuchia) dans le Crétacé Supérieur du Brésil. Implications paléobiogéographiques. In: Comptes Rendus de l' Académie des Sciences de Paris, série II, 301, pp. 1221-1224.

Buffetaut, E. (1989) A new ziphodont mesosuchian crocodile from the Eocene of Algeria. Palaeontographica, v. 208, pp. 1-10.

Buffetaut, E. and Taquet, P. (1979) An early Cretaceous terrestrial crocodilian and the opening of the South Atlantic. Nature, v. 280 , pp. $486-487$.

Busbey III, A.B. (1986) New material of Sebecus cf. huilensis (Crocodilia: Sebecosuchidae) from the Miocene La Venta Formation of Colombia. J. Vertebrate Paleontol., v. 6, pp. 20-27.

Calvo, J.O. and Salgado, L. (1996) A land bridge connection between South America and Africa during Albian-Cenomanian times based on sauropod dinosaur evidence. In: Congresso Brasileiro de Geologia, 39, 1996. Salvador, Anais. Soc. Brasil. de Geol. - Núcleo Bahia-Sergipe, pp. 392-393.

Campanha, V.A., Etchebehere, M.L.C., Saad, A.R. and Fulfaro, V.J. (1992) O significado paleogeográfico das novas ocorrências fossilíferas do Grupo Bauru na região do Triângulo Mineiro, MG. In: Simp. Sobre as Bacias Cretácicas Brasil., 2, 1992. Resumos Expandidos, Rio Claro, 1992, UNESP, pp. 151-152.

Campos, D.A., Suarez, J.M., Riff, D. and Kellner, A.W.A. (2001) Short note on a new Baurusuchidae (Crocodyliformes, Metasuchia) from the Upper Cretaceous of Brazil. Bol. do Museu Nacional, Geologia, 57, 7p.

Carvalho, I.S. and Bertini, R.J. (1998) Paleoenvironments of the Brazilian Cretaceous notosuchians. In: Crocodilian Biology and Evolution Conference, 1998. Prog. and Abst. Australia, Dept. of Zoology, The Univ. of Queensland, pp. 19.

Carvalho, I.S. and Bertini, R.J. (1999) Mariliasuchus, um novo Crocodylomorpha (Notosuchia) do Cretáceo da Bacia Bauru, Brasil. Rev. Geol. Colombiana, v. 24, pp. 83-105.

Carvalho, I.S. and Bertini, R.J. (2000) Contexto geológico dos notossúquios (Crocodylomorpha) cretácicos do Brasil. Rev. Geol. Colombiana, v. 25, pp. 163-184.

Carvalho, I.S., Ribeiro, L.C.B. and Avilla, L.S. (2004) Uberabasuchus terrificus sp. nov., a new crocodylomorpha from the Bauru Basin (Upper Cretaceous), Brazil. Gondwana Res., v. 7, pp. 975-1002.

Castro, J.C., Dias-Brito, D., Musacchio, E.A., Suarez, J., Maranhão, M.S.A.S. and Rodrigues, R. (1999) Arcabouço estratigráfico do Grupo Bauru no oeste Paulista. In: Simpósio Sobre o Cretáceo do Brasil, 5, 1999. Bol., Serra Negra, UNESP, pp. 509-515.

Clark, J.M. (1997) Patterns of evolution in Mesozoic Crocodyliformes. In: Fraser, N.C. and Sues, H.D. (Eds.), In the shadow of the dinosaurs. Early Mesozoic tetrapods. Cambridge Univ. Press, pp. 84-97. 
Colbert, E.H. (1946) Sebecus, representative of a peculiar suborder of fossil Crocodilia from Patagonia. Bull. Amer. Museum of Natural History, v. 87, pp. 217-270.

Dias-Brito, D. (1995) Calcisferas e microfácies em rochas carbonáticas pelágicas mesocretáceas. Prog. de PósGraduação em Geociências, Univ. Federal do Rio Grande do Sul, D.Sc., 688p.

Dias-Brito, D. (2002) Registros de calpionelideos no Cretáceo do Atlântico Sul: significado paleocenográfico e implicações. In: Simp. Sobre o Cretáceo do Brasil, 6, 2002. Bol., São Pedro, UNESP, pp. 311-316.

Dias-Brito, D., Musacchio, E.A., Castro, J.C., Maranhão, M.S.A.S., Suárez, J.M. and Rodrigues, R. (2001) Rev. Paleobiol., v. 20, pp. 245-304.

Estes, R. and Price, L.I. (1973) Iguanid lizard from the Upper Cretaceous beds of Brazil. Science, v. 180, pp. 748-751.

Etchebehere, M.L.C., Fulfaro, V.J., Saad, A.R. and Perinotto, J.A.J. (1999) O significado estratigráfico da calcretização por água subterrânea no Triângulo Mineiro, Sudoeste do Estado de Minas Gerais, Brasil. In: Simp. Sobre o Cretáceo do Brasil, 5, 1999. Bol., Serra Negra, UNESP, pp. 427-431.

Fernandes, L.A. and Coimbra, A.M. (1992) A cobertura cretácea suprabasáltica no Estado do Paraná e Pontal do Paranapanema. In: Cong. Brasil. Geol., 37, 1992. Resumos Expandidos, v. 2, pp. 506-508.

Fernandes, L.A. and Coimbra, A.M. (1996) A Bacia Bauru (Cretáceo Superior, Brasil). Anais da Academia Brasil. de Ciências, 68, pp. 195-205.

Fernandes, L.A. and Coimbra, A.M. (1999) Paleocorrentes da parte oriental da Bacia Bauru (KS, Brasil). In: Simp. Sobre o Cretáceo do Brasil, 5, 1999. Bol., Serra Negra, UNESP, pp. 51-57.

Fulfaro, V.J., Perinotto, J.A.J. and Barcelos, J.H. (1994) A margem goiana do Grupo Bauru: implicações na litoestratigrafia e paleogeografia. In: Simp. Sobre o Cretáceo do Brasil, 3, 1994. Bol., Rio Claro, UNESP, pp. 81-84.

Fulfaro, V.J., Etchebehere, M.L.C., Perinotto, J.A.J. and Saad, A.R. (1999) Bacia Caiuá: uma nova bacia cretácea na Bacia do Paraná. In: Simpósio Sobre o Cretáceo do Brasil, 5, 1999. Bol., Serra Negra, UNESP, pp. 439-442.

Garcia, A.J.V., da Rosa, A.A.S. and Goldberg, K. (1999) Paleoenvironmental and palaeoclimatic controls on early diagenetic processes and fossil records in continental Cretaceous sandstones in Brazil: a petrologic approach. In: Simpósio Sobre o Cretáceo do Brasil, 5, 1999. Bol., Serra Negra, UNESP, pp. 491-495.

Gasparini, Z.B. (1972) Los Sebecosuchia (Crocodilia) del Territorio Argentino. Consideraciones sobre su "status" taxonomico. Ameghiniana, v. 9, pp. 23-34.

Gasparini, Z.B. (1981) Los Crocodylia fosiles de la Argentina. Ameghiniana, v. 18, pp. 177-205.

Gasparini, Z. B. (1982) Una nueva família de cocodrilos zifodontes cretácicos de América Del Sur. In: Congreso Latinoamericano de Geología, 5, 1981. Actas, v. 4, Buenos Aires, pp. 317-329.

Gasparini, Z.B. (1996) Biogeographic evolution of the South American crocodilians. München Geowiss. Abh., v. A(30), pp. 159-184.

Gasparini, Z.B., Chiappe, L.M. and Fernandez, M. (1991) A new Senonian peirosaurid (Crocodylomorpha) from Argentina and a sinopsis of the South American Cretaceous crocodilians.
J. Vertebrate Paleontol., v. 11, pp. 316-333.

Gasparini, Z.B., Fernandez, M. and Powell, J. (1993) New tertiary Sebecosuchians (Crocodylomorpha) from South America: phylogenetic implications. Historical Biol., v. 7, pp. 1-19.

Gobbo-Rodrigues, S.R., Santucci, R.M. and Bertini, R.J. (2001) Considerações sobre a idade da Formação Marília (Grupo Bauru, Cretáceo Superior) na região de Peirópolis, Estado de Minas Gerais. In: Cong. Brasil. de Paleontol., 17, 2001. Bol. de Resumos, Rio Branco, UFA, p. 48.

Goldberg, K. and Garcia, A.J.V. (2000) Palaeobiogeography of the Bauru Group, a dinosaur-bearing Cretaceous unit, northeastern Paraná Basin, Brazil. Cretaceous Res., v. 21, pp. 241-254.

Gomani, E.M. (1997) A crocodyliform from the Early Cretaceous Dinosaur Beds, Northern Malawi. J. Vertebrate Paleontol., v. 17 , pp. 280-294.

Hecht, M.K. and Tarsitano, S.F. (1983) On the cranial morphology of the Protosuchia, Notosuchia and Eusuchia. Neues Jahrbüch Geol. Paläontol. Monatshefte, v. 11, pp. 657-668.

Iordansky, N.N. (1973) The skull of the Crocodilia. In: Gans and T. S. Parsons (Eds.), Biology of the reptilia, 4. C., London and New York, Academic Press, pp. 201-262.

Kischlat, E.E., Barberena, M.C. and Timm, L.L. (1994) Considerações sobre a queloniofauna do Grupo Bauru, Neocretáceo do Brasil. In: Simp. Sobre o Cretáceo do Brasil, 3, 1994. Bol., Rio Claro, UNESP, pp. 105-107.

Kuhn, O. (1968) Die vorzeitlichen Krokodile. Verlag Oeben, Krailling bei München, 124p.

Langston Jr., W. (1956) The Sebecosuchia: cosmopolitan crocodilians? Amer. J. Science, v. 254, pp. 605-614.

Larsson, H.C.E. and Gado, B. (2000) A new Early Cretaceous crocodyliform from Niger. Neues Jahrbüch Geol. Paläontol. Abh., v. 217, pp. 131-141.

Lima, M.R., Mezzalira, S., Dino, R. and Saad, A.R. (1986) Descoberta de microflora em sedimentos do Grupo Bauru, Cretáceo do Estado de São Paulo. Rev. do Instituto de Geociências da Univ. São Paulo, v. 7, pp. 5-9.

Magalhães Ribeiro, C.M. (2000) Microstructural analysis of dinosaur eggshells from Bauru Basin (Late Cretaceous), Minas Gerais, Brasil. In: Int. Symp. on Dinosaur Eggs and Babies, $1^{\text {st }}$, 2000. Ext. Abst., pp. 117-121.

Magalhães Ribeiro, C.M. and Ribeiro, L.C.B. (1999) Um ovo de dinossauro em sucessões fluviais da Formação Marília (Cretáceo Superior), em Peirópolis (Uberaba, Minas Gerais). In: Simp. de Geologia do Sudeste, 6, 1999. Bol. de Resumos, São Pedro, pp. 76.

Manzini, F.F., Brandt Neto, M. and Vizotto, L.D. (1996) Cintura pélvica de Baurusuchus pachecoi Price, 1945 em sedimentos da Formação Adamantina (Grupo Bauru, Cretáceo Superior). In: Simp. Sobre o Cretáceo do Brasil, 4, 1996. Bol., Águas de São Pedro, UNESP, pp. 273-276.

Markwick, P.J. (1998) Fossil crocodilians as indicators of Late Cretaceous and Cenozoic climates: implications for using palaeontological data in reconstructing palaeoclimate. Palaeogeogr., Palaeoclim., Palaeoecol., v. 137, pp. 205-271.

Mezzalira, S. (1980) Aspectos paleoecológicos da Formação Bauru. In: Mesa Redonda: A Formação Bauru no Estado de São Paulo e regiões adjacentes. Publicação Especial da Soc. Brasil. Geol., v. 7, pp.1-9.

Mourer-Chauviré, C. (1981) Première indication de la présence 
de Phorusrhacidés, famille d'oiseaux géants d'Amérique du Sud, dans le Tertiaire Européen: Ameghinornis nov. gen. (Aves, Ralliformes) des Phosphorites du Quercy (France). Geobios, v. 14, pp. 637-646.

Mourer-Chauviré, C. (1982) Réponse de C. Mourer-Chauviré. Geobios, v. 15, pp. 268-269.

Musacchio, E.A. (2000) Biostratigraphy and biogeography of Cretaceous charophytes from South America. Cretaceous Res., v. 21, pp. 211-220.

Nobre, P.H. and Carvalho, I.S. (2001) Morfologia do crânio de Candidodon itapecuruense, um Crocodylomorpha (Notosuchia) cretácico do Brasil. Rev. Brasileira de Paleontol., v. 2, pp. 144-145.

Ortega, F., Buscalioni, A.D. and Gasparini, Z. (1996) Reinterpretation and new denomination of Atacisaurus crassiproratus (Middle Eocene, Issel, France) as cf. Iberosuchus (Crocodylomorpha, Metasuchia). Geobios, v. 29, pp. 353-364.

Ortega, F., Gasparini, Z., Buscalioni, A.D. and Calvo, J.O. (2000) A new species of Araripesuchus (Crocodylomorpha, Mesoeucrocodylia) from the Lower Cretaceous of Patagonia (Argentina). J. Vertebrate Paleontol., v. 20, pp. 57-76.

Prasad, G.V.R. and Broin, F.L. (2002) Late Cretaceous crocodile remains from Naskal (India): comparisons and biogeographic affinities. Annales de Paléontol., v. 88, pp. 19-71.

Pol, D. (1999) Basal Mesoeucrocodylian relationships: new clues to old conflicts. J. Vertebrate Paleontol., Abst., v. 19, pp. 69 A.

Pol, D. (2003) New remains of Sphagesaurus huenei (Crocodylomorpha: Mesoeucrocodylia) from the Late Cretaceous of Brazil. J. Vertebrate Paleontol., v. 23, pp. 817-831.

Petri, S. (1955) Carophytas cretácicas de São Paulo. Bol. Soc. Brasil. Geol., v. 4, pp. 67-74.

Price, L.I. (1945) A new reptile from the Cretaceous of Brazil. Rio de Janeiro, Departamento Nacional da Produção Mineral, Notas preliminares e estudos, Bol. 25, 8p.

Price, L.I. (1950a) On a new Crocodilia, Sphagesaurus from the Cretaceous of the state of São Paulo, Brazil. Anais da Academia Brasil. de Ciências, v. 22, pp. 77-83.

Price, L.I. (1950b) Os crocodilídeos da fauna da formação Bauru, do Cretáceo terrestre do Brasil meridional. Anais da Academia Brasil. de Ciências, v. 22, pp. 473-490.

Price, L.I. (1955) Novos crocodilídeos dos arenitos da Série Bauru. Cretáceo do Estado de Minas Gerais. Anais da Academia Brasil. de Ciências, v. 27, pp. 487-498.

Rage, J.C. (1981) Les continents péri-atlantiques au Crétacé supérieur: migrations des faunes continentales et. al. problèmes paléogéographiques. Cretaceous Res., v. 2, pp. 65-84.

Richardson, K.C., Webb, G.J.W. and Manolis, S.C. (2002) Crocodiles: inside out. A guide to the crocodilians and their functional morphology. Australia, Surrey Beatty and Sons. 172p.

Riff, D. and Kellner, A.W.A.K. (2001) On the dentition of Baurusuchus pachecoi Price (Crocodyliformes, Metasuchia) from the Upper Cretaceous of Brazil. Bol. Museu Nacional, Nova Série, Geologia, v. 59, pp. 1-15.

Romer, A.S. (1956) The osteology of the reptiles. Chicago, Univ. Chicago Press. 772p.

Roxo, M.G.O. (1936) On a new species of fossil Crocodilia from Brazil, Goniopholis paulistanus sp. n. Anais Acad. Brasil. de Ciências, v. 8, pp. 33-34.

Senra, M.C.E. and Silva e Silva, L.H. (1999) Moluscos dulçaqüícolas e microfósseis vegetais associados da Formação Marília, Bacia Bauru, (Cretáceo Superior), Minas Gerais, Brasil. In: Simp. Sobre o Cretáceo do Brasil, 5, 1999. Bol., Serra Negra, UNESP, pp. 497-500.

Silva, R.B., Etchebehere, M.L.C. and Saad, A.R. (1994) Groundwater calcretes: uma interpretação alternativa para os calcários da Formação Marília no Triângulo Mineiro. In: Simp. Sobre o Cretáceo do Brasil, 3, 1994. Bol., Rio Claro, UNESP, pp. 85-89.

Soares, P.C., Landim, P.M.B., Fulfaro, V.J. and Sobreiro Neto, A.F. (1980) Ensaio de caracterização estratigráfica do Cretáceo no Estado de São Paulo: Grupo Bauru. Rev. Brasil. Geociências, v. 10, pp. 177-185.

Suarez, J.M. and Arruda, M.R. (1968) Jazigo fossilífero no Grupo Bauru, contendo lamelibrânquios. In: Cong. Brasil. de Geol., 22, 1968. Anais, Belo Horizonte, Soc. Brasil. Geol., pp. 209-212.

Steel, R. (1973) Crocodylia. In: Handbuch der Paläoherpetologie. G. Fischer, Stuttgart and Portland, 16, 116p.

Tykoski, R.S., Rowe, T.B., Ketcham, R.A. and Colbert, M.W. (2002) Calsoyasuchus valliceps, a new crocodyliform from the Early Jurassic Kayenta Formation of Arizona. J. Vertebrate Paleontol., v. 22, pp. 593-611.

Wilson, J.A., Malkane, M.S., Gingerich, P.D. (2001) New crocodyliform (Reptilia, Mesoeucrocodylia) from the Upper Cretaceous Pab Formation of Vitakri, Balochistan (Pakistan). Contrib. from the Museum of Paleontology, Univ. Michingan, v. 30, pp. 321-336.

Witmer, L.M. (1997) The evolution of the antorbital cavity of archosaurs: a study in soft-tissue reconstruction in the fossil record with an analysis of the function of pneumaticity. J. Vertebrate Paleontol., Suppl. to No. 1, Mem. 3, v. 17, 78p.

Woodward, A.S. (1896) On two Mesozoic crocodilians (Notosuchus genus novum and Cynodontosuchus genus novum) from the red sandstones of the territory of Neuquén. Ann. Museo de La Plata. Palaeont. Argentina, La Plata, v. 4, pp. 1-20. 